\title{
Water Quality and Sources of Fecal Coliform Bacteria in the Meduxnekeag River, Houlton, Maine
}

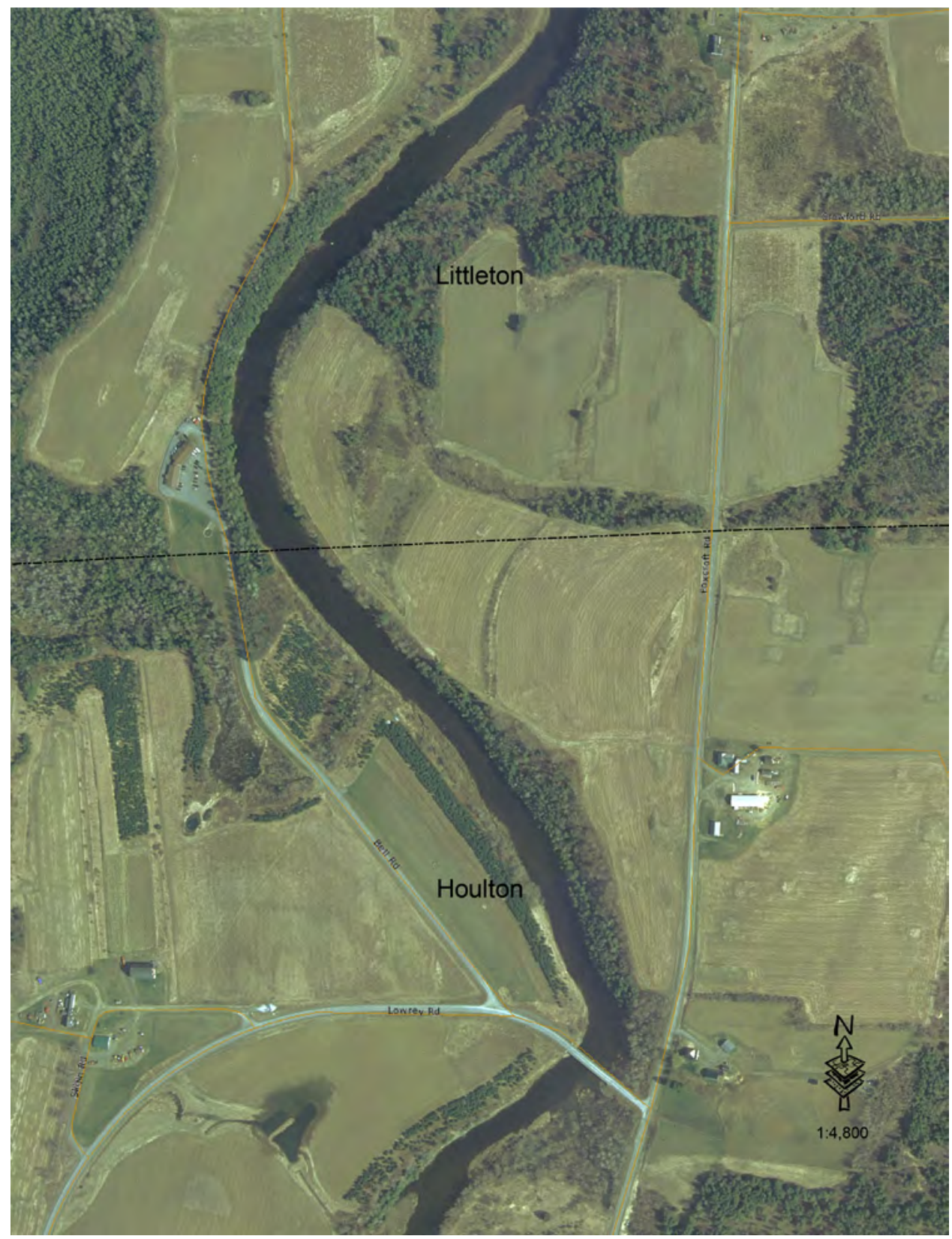

Scientific Investigations Report 2013-5144 
Cover. Houlton Band of Maliseet Indians Headquarters on the Meduxnekeag River, Littleton, Maine. Photograph: Maine GIS GeoLibrary, 2' Orthophotos, 2003-5. 


\section{Water Quality and Sources of Fecal Coliform Bacteria in the Meduxnekeag River, Houlton, Maine}

By Charles W. Culbertson, Thomas G. Huntington, Donald M. Stoeckel, James M. Caldwell, and Cara O'Donnell

Prepared in cooperation with the Houlton Band of Maliseet Indians

Scientific Investigations Report 2013-5144 


\title{
U.S. Department of the Interior SALLY JEWELL, Secretary
}

\section{U.S. Geological Survey Suzette M. Kimball, Acting Director}

\author{
U.S. Geological Survey, Reston, Virginia: 2014
}

For more information on the USGS - the Federal source for science about the Earth, its natural and living resources, natural hazards, and the environment, visit http://www.usgs.gov or call 1-888-ASK-USGS.

For an overview of USGS information products, including maps, imagery, and publications, visit http://www.usgs.gov/pubprod

To order this and other USGS information products, visit http://store.usgs.gov

Any use of trade, firm, or product names is for descriptive purposes only and does not imply endorsement by the U.S. Government.

Although this information product, for the most part, is in the public domain, it also may contain copyrighted materials as noted in the text. Permission to reproduce copyrighted items must be secured from the copyright owner.

Suggested citation:

Culbertson, C.W., Huntington, T.G., Stoeckel, D.M., Caldwell, J.M., and O'Donnell, Cara, 2014, Water quality and sources of fecal coliform bacteria in the Meduxnekeag River, Houlton, Maine: U.S. Geological Survey Scientific Investigations Report 2013-5144, 31 p., http://dx.doi.org/10.3133/sir20135144.

ISSN 2328-0328 (online) 


\section{Acknowledgments}

The authors thank the Houlton Wastewater Treatment Plant, Houlton, Maine, and the

Olentangy Environmental Control Center, Delaware, Ohio, for allowing the use of samples from their facilities. 



\section{Contents}

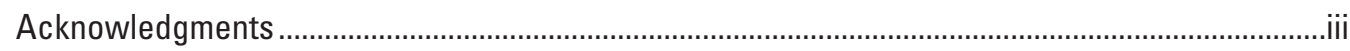

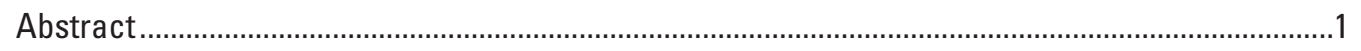

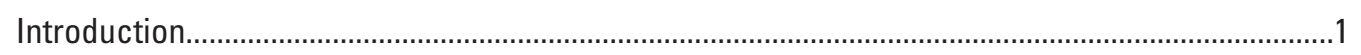

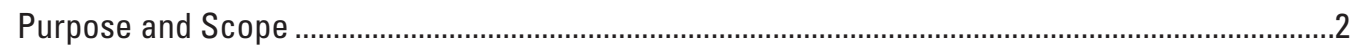

Previous Investigations ..........................................................................................................

Description of Study Area ....................................................................................................

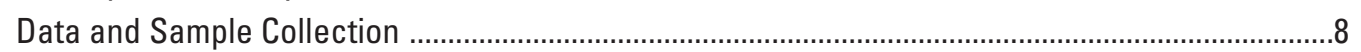

In Situ Water-Quality Parameters .....................................................................................

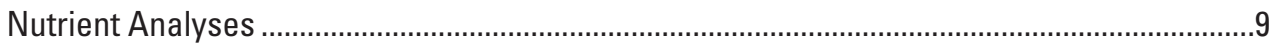

Sampling and Analysis of Fecal-Indicator Bacteria …...........................................................

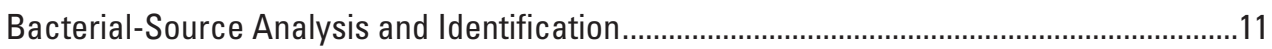

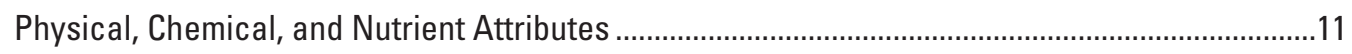

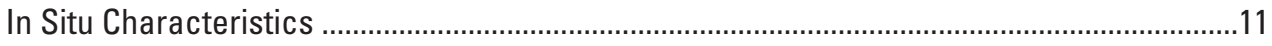

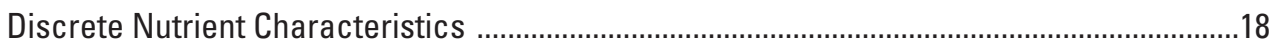

Distribution and Source of Fecal Indicator Bacteria ..............................................................

Fecal-Indicator Bacterial Densities.............................................................................. 19

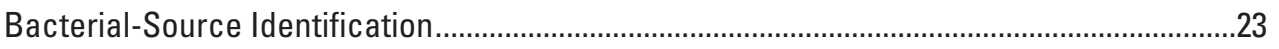

Enterococcus as an Indicator of Fecal Contamination ........................................................ 27

Factors Associated with Distribution of Fecal Contamination ................................................27

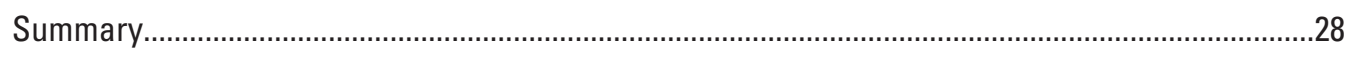

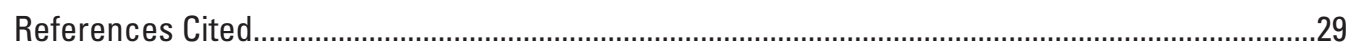

\section{Figures}

1. Map showing hydrography of the Meduxnekeag River watershed in northeastern Maine. Colors are used only to differentiate individual subbasins ...................................

2. Map showing location of data collection sites in the Meduxnekeag River watershed in northeastern Maine ......................................................................................................5

3. Map showing land cover of the Meduxnekeag River watershed in northeastern Maine

4. Graphs showing A, daily precipitation from June 1 through September 30, 2005, $B$, streamflow for the Meduxnekeag River at three sites near Houlton, Maine, from June through September 2005.

5. Graphs showing A, temperature, B, dissolved oxygen concentrations, $\mathrm{C}, \mathrm{pH}$, and $D$, specific conductance, in the Meduxnekeag River at three sites near Houlton, Maine.

6. Graph showing specific conductance in the Meduxnekeag River upstream of the Houlton Wastewater Treatment Plant (01018022) and downstream of the Houlton Wastewater Treatment Plant (01018025) near Houlton, Maine, from August through September 2005

7. Graph showing total phosphorus measured in discrete samples collected at the three streamgages 01018000,01018022 , and 01018035 from June through September $2005 . .19$ 
8. Graph showing total nitrogen concentrations measured in discrete samples collected at the three streamgages 01018000,01018022 , and 01018035 from June through September 2005.

9. Graphs showing bacterial counts (fecal-coliform colonies per 100 milliliters [mL]) in surface-water samples collected during the summers of indicated years at selected sites on the Meduxnekeag River and on the South Branch of the Meduxnekeag River

10. Graph showing medians of bacterial counts (fecal-coliform colonies per 100 milliliters [mL]) in surface-water samples collected during the summer of 2001 at upstream and downstream sites on selected tributaries to the Meduxnekeag River near Houlton, Maine.

11. Graphs showing bacterial counts (fecal-coliform colonies per 100 milliliters [mL]) in surface-water samples collected from rivers in Maine during the NASQAN program from 1976 through 1994 and from the Meduxnekeag River downstream of urban areas near Houlton, Maine, from 1998 through 2005

\section{Tables}

1. Water-quality and microbial-source sampling stations established by the U.S. Geological Survey in 2005, numbers of samples collected, and sampling dates on the Meduxnekeag River near Houlton, Maine....

2. Constituent name, U.S. Geological Survey National Water Information System parameter codes, and minimum reporting limits for temperature, specific conductance, dissolved oxygen, $\mathrm{pH}$, nutrients, and dissolved organic carbon

3. Meduxnekeag River main stem locations sampled for bacterial counts during the summers of 1998 through 2005

4. Water-quality sample results, Meduxnekeag River (and tributary inputs) near Houlton, Maine, 2005.

5. Results of bacterial source analysis of water samples collected from the Meduxnekeag River and tributaries near Houlton, Maine, 2005, and analyzed for markers.

6. Rainfall (inches) on sampling dates for bacterial-source tracking and cumulative rainfall on 1-, 2-, 3-, and 4-day periods before sampling dates 
Conversion Factors, Datum, and Abbreviations

\begin{tabular}{lcl}
\hline \multicolumn{1}{c}{ Multiply } & By & \multicolumn{1}{c}{ To obtain } \\
\hline inch (in.) & Length & \\
inch (in.) & 2.54 & centimeter $(\mathrm{cm})$ \\
foot (ft) & 25,445 & micrometer $(\mu \mathrm{m})$ \\
mile (mi) & 0.3048 & meter $(\mathrm{m})$ \\
\hline \multicolumn{3}{c}{} \\
\hline acre & 1.609 & kilometer $(\mathrm{km})$ \\
\hline square mile $\left(\mathrm{mi}^{2}\right)$ & Area & \\
\hline & 0.004047 & square kilometer $\left(\mathrm{km}^{2}\right)$ \\
\hline ounce, fluid (fl. oz) & 2.590 & square kilometer $\left(\mathrm{km}^{2}\right)$ \\
ounce, fluid (fl. oz) & Volume & \\
\hline & 29.568 & milliliter $(\mathrm{mL})$ \\
\hline cubic foot per second $\left(\mathrm{ft}^{3} / \mathrm{s}\right)$ & 29,568 & microliter $(\mu \mathrm{L})$ \\
\hline
\end{tabular}

Temperature in degrees Celsius $\left({ }^{\circ} \mathrm{C}\right)$ may be converted to degrees Fahrenheit $\left({ }^{\circ} \mathrm{F}\right)$ as follows:

$$
{ }^{\circ} \mathrm{F}=\left(1.8 x^{\circ} \mathrm{C}\right)+32
$$

Vertical coordinate information is referenced to the North American Vertical Datum of 1988 (NAVD 88).

Horizontal coordinate information is referenced to the North American Datum of 1983 (NAD 83).

Altitude, as used in this report, refers to distance above the vertical datum.

Specific conductance is given in microsiemens per centimeter at 25 degrees Celsius $\left(\mu \mathrm{S} / \mathrm{cm}\right.$ at $\left.25^{\circ} \mathrm{C}\right)$.

Concentrations of chemical constituents in water are given in milligrams per liter $(\mathrm{mg} / \mathrm{L})$, micrograms per liter ( $\mu \mathrm{g} / \mathrm{L})$, milligrams per kilogram $(\mathrm{mg} / \mathrm{kg})$, nanograms per liter $(\mathrm{ng} / \mathrm{L})$, nanograms per microliter $(\mathrm{ng} / \mu \mathrm{L})$, or picograms per microliter $(\mathrm{pg} / \mu \mathrm{L})$.

\title{
Abbreviations
}

\author{
BST bacterial-source tracking \\ CFU colony forming units \\ DDT dichloro-diphenyl-trichloroethane \\ DNA deoxyribonucleic acid \\ E. coli Escherichia coli \\ FIB fecal indicator bacteria \\ HBMI Houlton Band of Maliseet Indians \\ MST microbial source tracking \\ mTEC membrane Thermotolerant Escherichia coli \\ mEl membrane-Enterococcus Indoxyl- $\beta$ - $D$-glucoside
}




$\begin{array}{ll}\text { NCDC } & \text { National Climatic Data Center } \\ \text { NOAA } & \text { National Oceanic and Atmospheric Administration } \\ \text { NPP } & \text { net primary production } \\ \text { NWIS } & \text { National Water Information System } \\ \text { NWOL } & \text { National Water-Quality Laboratory } \\ \text { OWML } & \text { Ohio Water Microbiology Laboratory } \\ \text { PCR } & \text { polymerase chain reaction } \\ \text { RM } & \text { river mile } \\ \text { RNA } & \text { ribonucleic acid } \\ \text { SC } & \text { specific conductance } \\ \text { TMDL } & \text { total maximum daily load } \\ \text { USEPA } & \text { U.S. Environmental Protection Agency } \\ \text { USGS } & \text { U.S. Geological Survey } \\ \text { WWDP } & \text { wastewater discharge point } \\ \text { WWTP } & \text { wastewater treatment plant }\end{array}$




\title{
Water Quality and Sources of Fecal Coliform Bacteria in the Meduxnekeag River, Houlton, Maine
}

\author{
By Charles W. Culbertson', Thomas G. Huntington', Donald M. Stoeckel ${ }^{2}$, James M. Caldwell', and \\ Cara O'Donnell ${ }^{3}$
}

\section{Abstract}

In response to bacterial contamination in the Meduxnekeag River and the desire to manage the watershed to reduce contaminant sources, the Houlton Band of Maliseet Indians (HBMI) and the U.S. Geological Survey began a cooperative effort to establish a baseline of water-quality data that can be used in future studies and to indicate potential sources of nutrient and bacterial contamination. This study was conducted during the summer of 2005 in the Meduxnekeag River Basin near Houlton, Maine. Continuously recorded specific conductance can be a good indicator for water quality. Specific conductance increased downstream from the town of Houlton, between runoff events, and decreased sharply following major runoff events. Collections of discrete samples during the summer of 2005 indicated seasonal positive concentration-discharge relations for total phosphorus and total nitrogen; these results indicate that storm runoff may mobilize and transport these nutrients from the terrestrial environment to the river. Data collected by the HBMI on fecal coliform bacteria indicated that bacterial contamination enters the Meduxnekeag River from multiple paths including tributaries and surface drains (ditches) in developed areas in Houlton, Maine. The Houlton wastewater treatment discharge was not an important source of bacterial contamination.

Bacteroidales-based tests for general fecal contamination (Bac32 marker) were predominantly positive in samples that had excessive fecal contamination as indicated by Enterococci density greater than 104 colony-forming units per 100 millilters. Of the 22 samples tested for Bacteroidales-based markers of human-associated fecal contamination (HF134 and HF183), 8 were positive. Of the 22 samples tested for Bacteroidales-based markers of ruminant-associated fecal contamination (CF128 and CF193), 7 were positive. Human fecal contamination was detected consistently at two sites

\footnotetext{
${ }^{1}$ U.S. Geological Survey.

${ }^{2}$ Battelle Memorial Institute, Columbus, Ohio.

${ }^{3}$ Houlton Band of Maliseet Indians.
}

(surface drains in urban areas in the town of Houlton) and occasionally detected at one site (Moose Brook) but was not detected at other sites. Fecal contamination (as indicated by fecal coliform density) apparently is localized under normal flow conditions with the highest levels restricted to drains in urban areas and to a lesser extent B Stream, Pearce Brook, and Big Brook, all tributaries to the main stem of the Meduxnekeag River. Coliphage were enumerated as an alternate indicator of fecal contamination with the intent of typing the virus into host-associated classes (human or ruminant), as was done for Enterococci; however, insufficient coliphage were isolated to provide more than preliminary indications. In spite of low coliphage enumeration, the preliminary results strengthen the conclusion that the Enterococci data correctly indicated the samples that contained human and ruminant fecal contamination. The finding that contamination was in many of the tributaries following storms in mid-July indicates that storm runoff likely carries fecal contaminants to more locations than runoff under lower flow conditions.

\section{Introduction}

Water quality in the Meduxnekeag River, as in the rest of the United States, is affected by both point and nonpoint sources associated with agricultural (through runoff from livestock waste and animal feedlots, erosion, and pesticides), urban commercial and residential (through stormwater runoff and sewer overflow), rural residential (wildlife and leachate from septic systems), and industrial (through wastewater and thermal effects) land use. Bacterial contamination is most closely associated with development and is lowest in the upper reaches of forested watersheds. Sediment, nutrients, and organic compounds from agricultural, urban, and industrial land uses are likely mobilized during seasonal periods of high runoff. The assessment of contaminants in receiving waters can provide information about the nature, magnitude, and scope of the surface-water contamination and direct local managers toward possible methods of mitigation (Dombek and others, 2000; U.S. Environmental Protection Agency, 2000). 
Surface water contaminated with fecal-derived pathogens continues to be a widespread problem in the U.S. despite the goal that waters be "fishable and swimmable" as stated in the 1972 Clean Water Act (U.S. Environmental Protection Agency, 2000). Waters contaminated by fecal coliform bacteria (fecal coliforms) may create negative social and economic consequences for communities through the loss of potable water and recreational activities (U.S. Environmental Protection Agency, 2000). Because contamination of surface waters by fecal coliforms is a threat to human health, water bodies are required to meet criteria for the concentrations of fecal coliform indicator organisms, a category which includes Escherichia coli, Clostridium perfringens, and fecal Streptococci and Enterococci (U.S. Environmental Protection Agency, 2002a). The most common contaminant in streams and rivers throughout the U.S. is fecal coliforms at concentrations that exceed U.S. Environmental Protection Agency (USEPA) criteria (U.S. Environmental Protection Agency, 2002b). Waters contaminated with human and animal feces pose an elevated human health risk because of the likely presence of human-specific enteric pathogens such as Salmonella enterica serovar Typhi, Shigella spp., hepatitis A virus, and Norwalk-group viruses; and animal-specific enteric pathogens such as serotypes of Salmonella, Escherichia coli, and Cryptosporidium spp. (Scott and others, 2002).

Although fecal coliform contamination of surface waters is attributable to both point and nonpoint sources, contamination from nonpoint sources has surpassed that from industrial and municipal point sources in the U.S. (U.S. Environmental Protection Agency, 1990, 1996, 2003, 2005). Multiple and changing demands on land use in watersheds has made it difficult to identify and quantify nonpoint sources of pollution; this challenging problem can create conflict between groups having different interests in a particular water resource (Meays and others, 2004).

Waterborne pathogens, including viruses, are difficult to detect and quantify; consequently, several methods for monitoring fecal indicator bacteria (FIB) as proxies for the presence of pathogens have been developed. These molecular, biochemical, and chemical methods can be divided into culture-based and culture-independent methods; some methods are further categorized as "library-dependent" or "library-independent" (Simpson and others, 2002; Meays and others, 2004; Field and Samadpour, 2007; Stoeckel and Harwood, 2007). Because performance and validation criteria differ among the methods, no single standard method for bacterial-source tracking (BST) has yet been adopted for use in laboratory or field studies (Meays and others, 2004; Stoeckel and Harwood, 2007). The choice of an appropriate BST method and study design might logically be based not only on the ecological setting of the affected water resource but also on the specific type of FIB monitoring needed, an assessment of exposure and health risk, and other objectives of the investigation (Simpson and others, 2002; Meays and others, 2004; Stoeckel and Harwood, 2007). Although the presence of some FIB can be poorly correlated with specific pathogenic species or viruses (Meays and others, 2004; Field and Samadpour, 2007), the presence of fecal coliforms, nonetheless, is a likely indicator that some type of fecal contamination is present (Meays and others, 2004). Contaminant mitigation, in large part, depends on determining the nature and source of the contamination.

In response to bacterial contamination in the Meduxnekeag River and the desire to mitigate contaminant sources in the watershed, the Houlton Band of Maliseet Indians (HBMI) and the U.S. Geological Survey (USGS) began a cooperative effort to identify potential sources of bacterial contamination to the Meduxnekeag River near Houlton, Maine. This study was conducted during the summer of 2005 in the Meduxnekeag River basin near Houlton, Maine (fig. 1).

\section{Purpose and Scope}

This report presents information on the distribution and potential source(s) of fecal coliform bacteria and nutrient contaminants and provides water-quality and bacteria-source tracking (BST) information for the Meduxnekeag River near Houlton, Maine during the 2005 growing season (June through September). The report also describes results from water-quality, bacterial-count, and bacteria-source sampling at 19 locations on the main stem of the Meduxnekeag River upstream and downstream of the town of Houlton and its wastewater discharge point and on tributaries receiving runoff from areas of different land uses. Data collected by the HBMI during a longer time period (1998-2005) on fecal coliform bacterial density distributions are also presented to place the data from the more intensively studied 2005 summer season in a broader temporal context. These data serve three purposes: (1) to establish a baseline of water-quality data that can be used in future studies, (2) to indicate the response of certain water-quality parameters to changing flow conditions during the summer of 2005, and (3) to indicate potential sources of nutrient and bacterial contamination.

\section{Previous Investigations}

The HBMI has been actively involved in land- and water-resource management programs to improve the quality of water in the Meduxnekeag River watershed. During the past 15 years, the HBMI has observed seasonal diminished waterquality conditions in the Meduxnekeag River and in some of its tributaries near Houlton, Maine. Water-quality impairment has included high sediment loads during runoff, seasonal episodic filamentous algal blooms, elevated concentrations of fecal-coliform bacteria and inorganic nutrients, and low dissolved oxygen concentrations (unpublished data on file with the HBMI). 


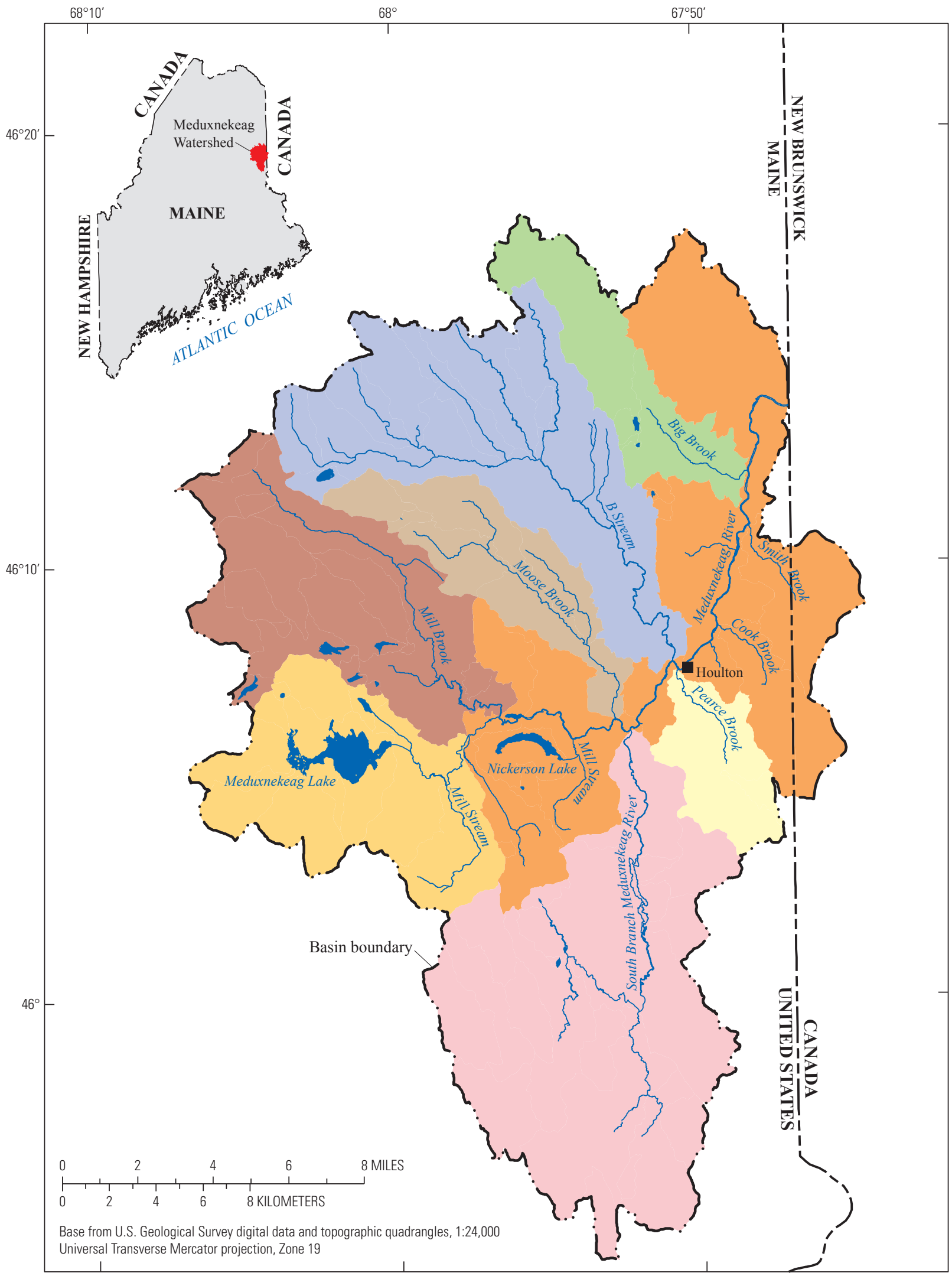

Figure 1. Hydrography of the Meduxnekeag River watershed in northeastern Maine. Colors are used only to differentiate individual subbasins. 
Fish-consumption advisories have been issued for the Meduxnekeag River because of elevated levels of the pesticide dichloro-diphenyl-trichloroethane (DDT) in fish tissue (Maine Department of Environmental Protection, 2002) and for all Maine rivers because of elevated levels of mercury in fish tissue (Maine Department of Environmental Protection, 1998b). Nuisance algal growth downstream from the Houlton Water Company wastewater discharge point (WWDP) was documented in the mid-1990s to be a result of high concentrations of phosphorus; thus, a total maximum daily load (TMDL) standard for total phosphorus was subsequently established (Maine Department of Environmental

Protection, 2000).

In a 2003 study, seasonal concentrations of nutrients (nitrogen and phosphorus), organic compounds, and mercury in the surface water and bed sediments of Meduxnekeag River were measured; and the possible role of streambed sediment as a source of nutrients to surface water during summer periods of low flow was investigated. Sediments in general were difficult to find because of the rocky nature of the Meduxnekeag River streambed; sediments that were collected were found to be shallow and sandy, containing little organic matter (Schalk and Tornes, 2005). Concentrations of phosphorus in bed sediment were less than 700 milligrams per kilogram $(\mathrm{mg} / \mathrm{kg})$ in all samples. Phosphorus was not detected or was at concentrations below the reporting limit $(40 \mathrm{mg} / \mathrm{kg}$ ) in most surface-water samples, whereas nitrate was detected in every surface-water sample at concentrations greater than the reporting limit but less than or equal to 0.50 milligram per liter $(\mathrm{mg} / \mathrm{L})$. On the basis of flow percentages and drainage areas, instantaneous nitrogen loads during two medium- to high-flow events were disproportionately higher in the part of the watershed that is downstream from streamgage 01018000 (fig. 2) and includes the town of Houlton and its WWDP than in other parts of the watershed (Schalk and Tornes, 2005).

Relations among nutrient concentrations, nutrient sources, and algal growth in the Meduxnekeag River watershed were investigated during the summers of 2004 and 2005 (Fretwell, 2006). Although nutrient concentrations were low, mean concentrations of nitrate and total phosphorus increased with distance downstream during both summers. Mean nutrient concentrations spiked at sampling sites downstream from substantial inflows, such as the confluence of the South Branch, which transports runoff from a watershed with predominantly agricultural land use, and the Houlton WWDP. Mean concentrations of dissolved reactive phosphorus (orthophosphate) were below the minimum reporting limit (1.0 micrograms per liter $(\mu \mathrm{g} / \mathrm{L}))$ at all sites except those just downstream from the Houlton WWDP (fig. 2). The primary source of nitrate was agricultural areas, whereas the primary source of phosphorus was the Houlton WWDP (Fretwell, 2006).

A follow-up study examined the use of a dualstreamgage, whole-stream metabolism model (WSMP, Bales and Nardi, 2007) to identify factors regulating algal growth and predict primary productivity in the river (Goldstein and others, 2009). A near-linear decrease in net primary production (NPP) was observed from upstream reaches to downstream reaches. Mean daily temperature and $\mathrm{pH}$ were consistent throughout all reaches; however, specific conductance, a conservative indicator of external aqueous inputs, increased in the reaches downstream from the Houlton WWDP. A possible explanation for the decrease in NPP was inputs of organic matter and nutrients from urban agricultural and wastetreatment sources (Goldstein and others, 2009).

Because of concerns about possible contamination from fecal coliform, the HBMI began a sampling program at several surface-water streamgages on the Meduxnekeag River in 1998 (fig. 2). Preliminary results from these studies confirmed fecal coliform contamination at some of these locations (unpublished data on file with the HBMI). The source of the bacterial contamination was unknown, although likely sources included humans (from septage), wildlife, domesticated animals, and livestock (from agricultural operations).

\section{Description of Study Area}

The Meduxnekeag River, which is in southeastern Aroostook County in northern Maine, drains 516 square miles $\left(\mathrm{mi}^{2}\right)$ (fig. 1) at its confluence with the St. John River in New Brunswick, Canada. The river begins at Meduxnekeag Lake, 8 miles (mi) west of the town of Houlton, Maine. The South Branch joins the Meduxnekeag River near Houlton where the river turns north-northeast, flowing for approximately $10 \mathrm{mi}$ before it crosses the U.S.-Canadian border and then to its confluence with the St. John River. Near Houlton, Maine, at the most downstream point where streamflow is measured by the USGS (streamgage 01018035), the drainage area is $257 \mathrm{mi}^{2}$ (fig. 2). At the U.S.-Canadian border, the Meduxnekeag River has a drainage area of $289 \mathrm{mi}^{2}$ (Fontaine and others, 1982). The length of the river is $67 \mathrm{mi}$, and the total length of the tributaries is $290 \mathrm{mi}$. The upstream areas of the watershed include many small lakes at a higher elevation than the agricultural land (fig. 3).

Northeastern Maine is characterized by cold winters and short, warm summers. The growing season lasts 100 to 125 days. Average annual precipitation is about 39 inches (in.). (National Oceanic and Atmospheric Administration, 2002), which includes the water equivalent of $95 \mathrm{in}$. of snow. Average temperatures range from $12{ }^{\circ} \mathrm{F}$ in January to $68^{\circ} \mathrm{F}$ in July. Although precipitation is distributed fairly evenly throughout the year, most of the annual streamflow occurs during the spring snowmelt period and before evapotranspiration increases following leafout. Snowmelt runoff has been observed to cause severe erosion in late winter and early spring (Southern Aroostook County Soil and Water Conservation District, 1993). Occasional large summer and fall storms can also result in substantial amounts of runoff and erosion. 


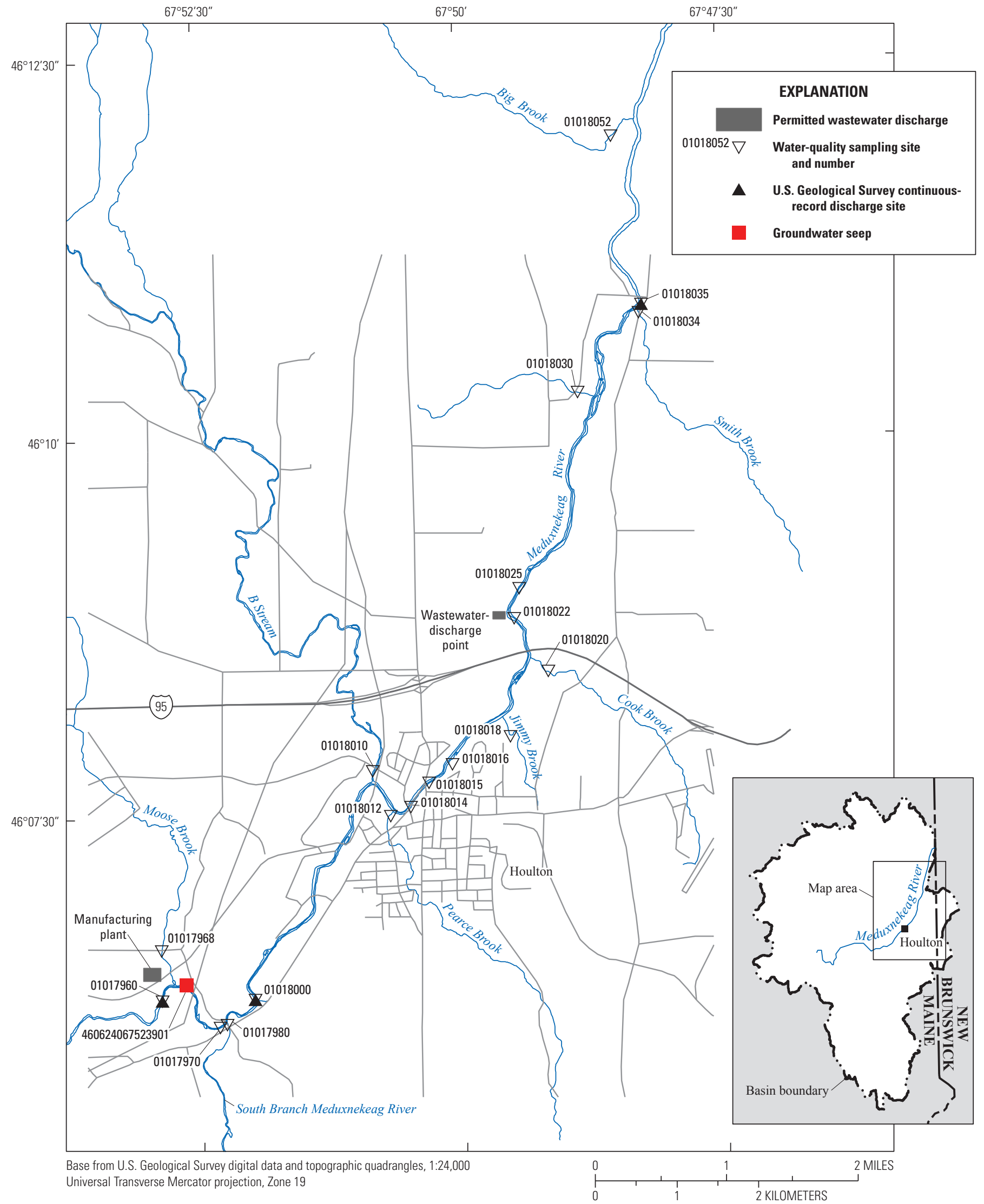

Figure 2. Location of data collection sites in the Meduxnekeag River watershed in northeastern Maine. 


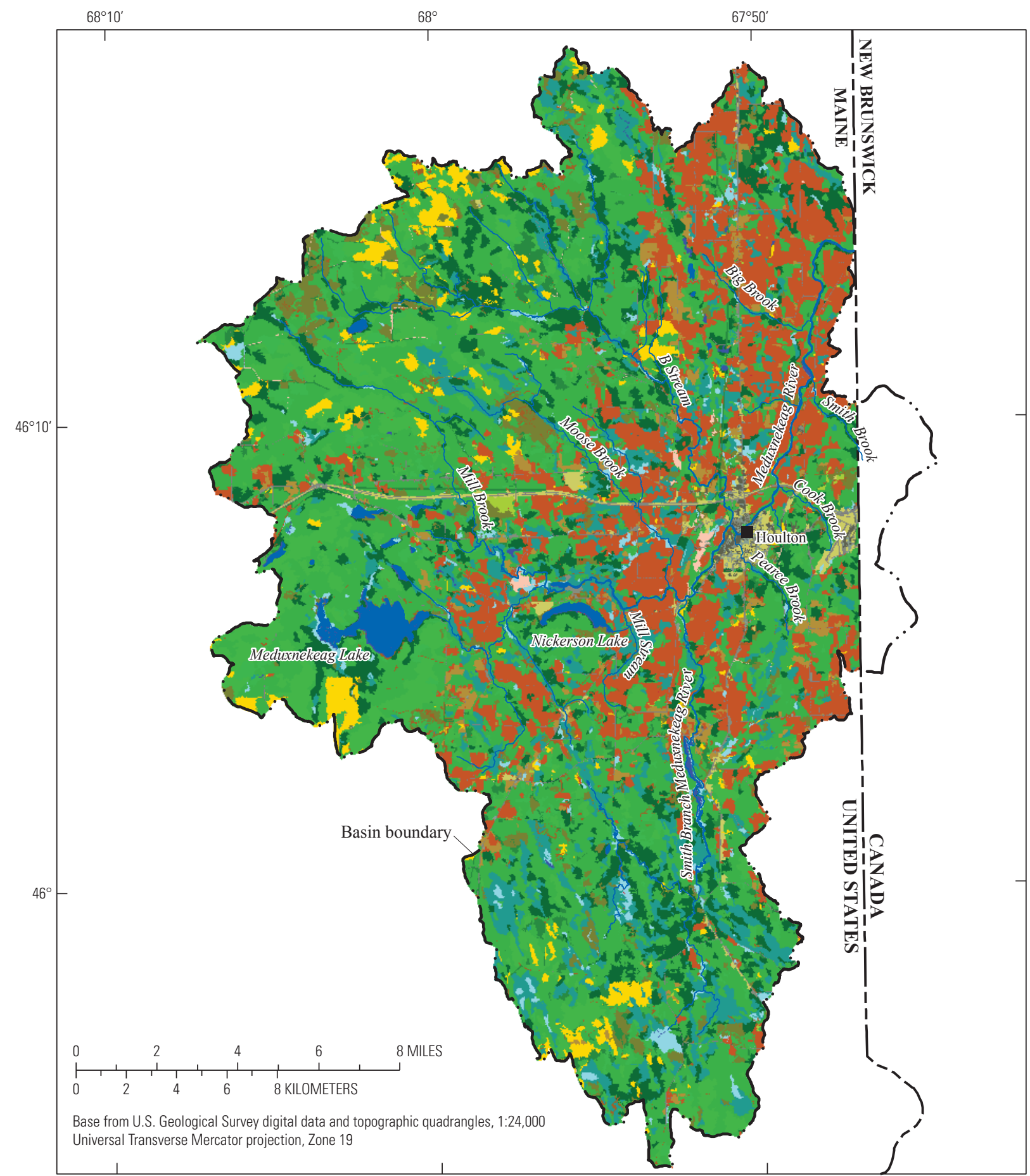

EXPLANATION

\begin{tabular}{|l|}
\hline Land-cover category \\
2 Developed, high intensity \\
3 Developed, medium intensity \\
4 Developed, low intensity \\
5 Developed, open \\
6 Cultivated crops \\
7 Pasture/hay \\
8 Grassland/herbaceous \\
9 Deciduous forest \\
\hline
\end{tabular}

10 Evergreen forest 11 Mixed forest 12 Scrub/shrub 13 Wetland forest 15 Wetlands 16 Road/runway 19 Unconsolidated shore 20 Bare ground

Figure 3. Land cover of the Meduxnekeag River watershed in northeastern Maine. 


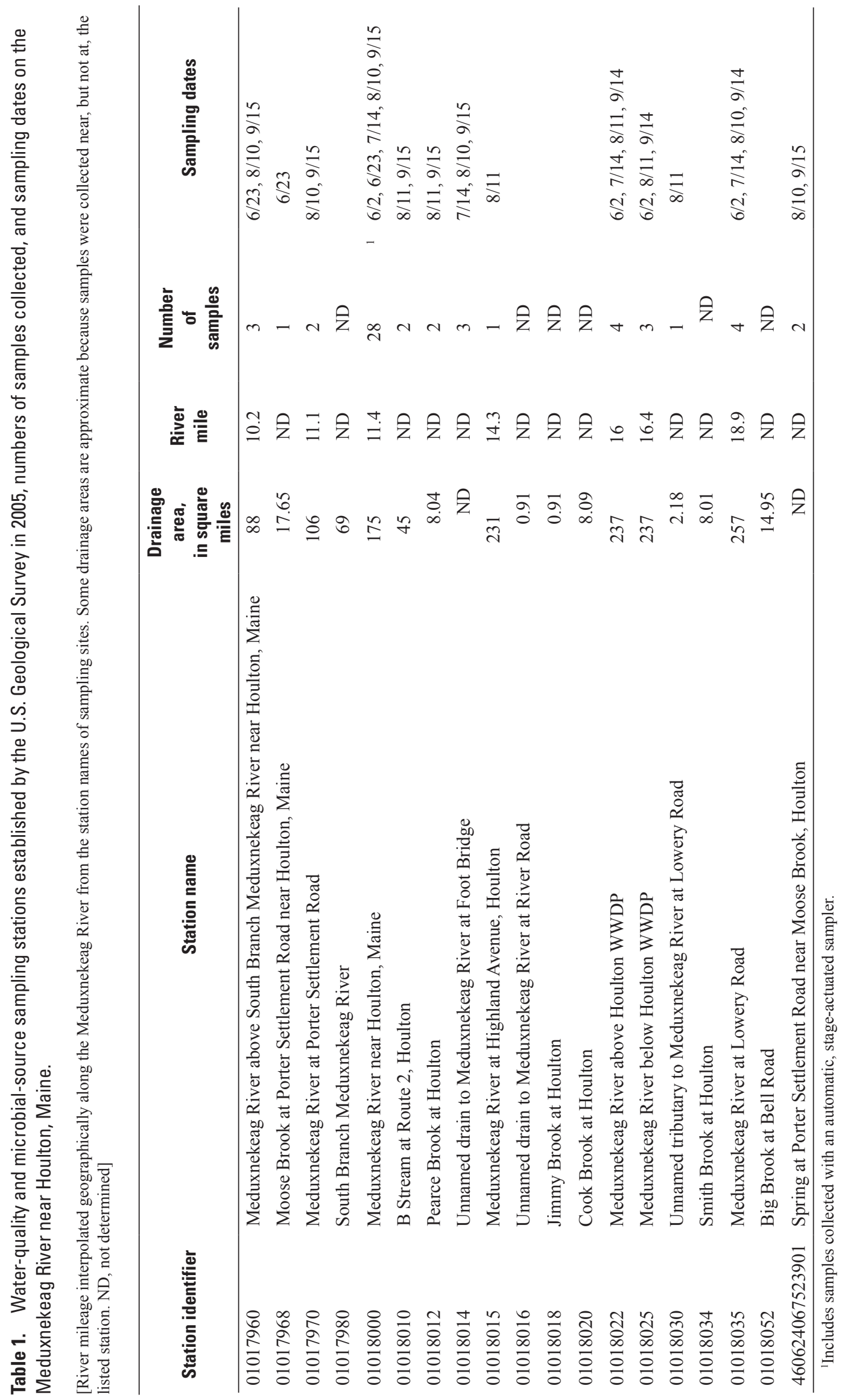


The USGS maintains three streamflow-gaging stations (or streamgages) in the study area (table 1, fig. 2). Streamgage 01017960, the most upstream streamgage, was established in 2003 in cooperation with Maine Department of Environmental Protection, Town of Houlton, and the Tate and Lyle Company, above the confluence of the main stem of the Meduxnekeag River and the South Branch. This streamgage is about 2 mi upstream from the town of Houlton, and the watersheds of its major tributaries Mill Stream and Mill Brook are primarily forested (figs. 1, 3). Long-term streamflow statistics for this streamgage were not calculated at this upstream site because of the short period of record. Streamgage 01018000, Meduxnekeag River near Houlton, was active from 1940 to 1982. During this time period, rating curves were established, and periodic measurements of water temperature, specific conductance, and streamflow were made. Streamgage 01018000 was reactivated in 2003 , in cooperation with the HBMI, for additional streamflow measurements and water-quality monitoring. Streamflow records from these streamgages were used to quantify streamflow in the Meduxnekeag River above the town of Houlton and allowed estimation of flow from South Branch but did not include flow from other downstream tributaries to the Meduxnekeag River. A third streamgage (the most downstream streamgage in the study area) was established in cooperation with the HBMI at Lowery Road (USGS streamgage 01018035) during the summer of 2005 (fig. 2). Streamflow measurements were made at 2 locations, Meduxnekeag River at Porter Settlement Road (USGS streamgage 01017970) and B Stream at Houlton (USGS streamgage 01018010), although continuous streamflow data were not collected at these locations (table 1). A typical annual hydrograph of flow at streamgage 01018000 is dominated by high spring runoff (late March to the middle of May) with relatively low flows during most of the rest of the year. Autumn rains can cause secondary peaks in October and November.

One town (Houlton, population 4,856 in 2010, U.S. Census Bureau, 2010) and one industry, a manufacturing plant, have permitted outfalls to the Meduxnekeag River (Maine Department of Environmental Protection, 1998a, 2003). Houlton's municipal wastewater-discharge point is just downstream from the town limits. The outfall of the manufacturing plant, which processes food starch (Town of Houlton, 2004), is just downstream from streamgage 01017960 and upstream from the confluence of the Meduxnekeag River with the South Branch (fig. 2).

Most agricultural fields are irrigated by withdrawals from the Meduxnekeag River and impoundments on the river (Matthew Williams, University of Maine Extension, written commun., 2004). The demand for irrigation water, however, puts stress on aquatic habitat during low-flow periods (Aroostook Water and Soil Management Board, 1996). Land cover in the Meduxnekeag River watershed upstream from streamgage 01018000 near Houlton is primarily forest with smaller amounts of agriculture (fig. 2, 3). Forests cover about 79 percent of the watershed; agricultural lands, about 17 percent; and urban areas and open water, about 4 percent (Southern Aroostook County Soil and Water Conservation District, 1993). Agricultural lands include 23,900 acres of active cropland, 3,900 acres of hay and pasture, and 3,000 acres of grassland; 393 farms of all sizes with 2,443 separate fields occupy 30,800 acres of agricultural land (Southern Aroostook County Soil and Water Conservation District, 1993). About 20,000 acres of potatoes, most commonly in rotation with grain, are grown on 212 farms. Fifty-two livestock operations support 2,350 animals, mostly dairy or beef cattle. Most of the agricultural land is concentrated in the lower half of the watershed in and downstream from the Houlton area. The general trend in land use is toward gradual increases in urban and suburban areas at the expense of agricultural and forested areas (Southern Aroostook County Soil and Water Conservation District, 1993).

The thickness of unconsolidated deposits in the Meduxnekeag River watershed is variable. In general, the overburden is calcareous till derived from weathered bedrock (Thompson and Borns, 1985). Much of the soil is classified as highly erodible or potentially highly erodible (Arno, 1964, U.S. Department of Agriculture, 1994). Most of the arable soils are in agricultural production, and the steep, stony, and poorly drained soils are in forests (Arno, 1964). Land surface is rolling, with hills reaching elevations of 200 to 500 feet (ft) above valley floors (Culbertson and others, 2013).

\section{Data and Sample Collection}

Measurements of water temperature, dissolved oxygen, $\mathrm{pH}$, and specific conductance were made at sites along a 10-mi transect of the Meduxnekeag River near Houlton, Maine during the summer of 2005. Water-quality-sampling (including bacteria) locations in the Meduxnekeag River watershed included several main-stem sites upstream and downstream from the town of Houlton and tributaries (fig. 2, table 1). Surface grab samples were collected at all sites with the exception of USGS streamgage 01018012 (fig. 2), where some of the samples were collected with an automatic stage-activated sampler. The intake for the automatic sampler was placed near the water level monitoring location which was about 7 centimeters $(\mathrm{cm})$ above the stream bottom and about $150 \mathrm{~cm}$ from the shoreline during summer lowflow conditions.

\section{In Situ Water-Quality Parameters}

In situ measurements of water temperature, $\mathrm{pH}$, specific conductance, and dissolved oxygen were measured continuously by use of YSI 600XL multiparameter probes installed at three streamgages in the Meduxnekeag River watershed (fig. 1). One of these probes was collocated with the sample-intake line of the automatic sampler deployed in 
Houlton at USGS streamgage 01018000 . The other probes were placed at streamgages 01018035 and 01017960 (fig. 2).

\section{Nutrient Analyses}

All samples collected for water-quality analysis were either filtered through a 0.45 -micrometer $(\mu \mathrm{m})$ Supor capsule filter or collected unfiltered, depending on the analyte. All samples were preserved according to USGS National Water Quality Laboratory (NWQL) protocols and kept on ice prior to shipment to the NWQL. All nutrient and inorganic laboratory analyses were done by the NWQL, and the results of these analyses were recorded in the National Water Information System (NWIS) database ${ }^{1}$. Samples were shipped on ice to the NWQL within 12-24 hours of collection. Samples were analyzed for dissolved inorganic nutrients (nitrate plus nitrite, nitrite, ammonium ion ${ }^{2}$, and orthophosphate), total phosphorus, total and dissolved organic nitrogen, and dissolved organic carbon (table 2).

\footnotetext{
${ }^{1}$ Standard NWQL analytical methods were used for all analyses (Fishman, 1993). Throughout this report, the notation "dissolved" in reference to laboratory-determined concentrations of analytes is identical to the notation "filtered" used in tables in this report in reference to NWQL analytes.

${ }^{2}$ Reported as ammonia. Dissolved organic nitrogen was not measured directly; it was estimated as total nitrogen (NWQL parameter code P62854) minus nitrite plus nitrate (NWQL parameter code P00631) and minus ammonia (NWQL parameter code P00608).
}

\section{Sampling and Analysis of Fecal- Indicator Bacteria}

Water samples were collected for measurement of fecal coliform density according to the procedures described by Bordner and others (1978). The HBMI sampled the Meduxnekeag River at numerous sites downstream from the outlet of Meduxnekeag Lake (fig. 1) to the Canadian border (table 3, fig. 1) during the summers of 1998 through 2005. During the summer of 2005, the USGS additionally collected samples for fecal coliform densities (table 3 ) at the same sites. Procedures for sample storage included refrigeration at a temperature of $1-4{ }^{\circ} \mathrm{C}$ in insulated containers during transport to the HBMI laboratory in Houlton, Maine. Holding times did not exceed 6 hours between collection and initiation of analyses. Samples were analyzed by HBMI for Escherichia coli (E. coli) in water by use of membrane filtration with modified membrane-Thermotolerant Escherichia coli Agar (Modified mTEC) according to U.S. Environmental Protection Agency method 1603 (U.S. Environmental Protection Agency, 2002d). Samples were also analyzed for Enterococci in water by use of membrane filtration with modified membraneEnterococcus Indoxyl-ß-D-Glucoside Agar (mEI) according to USEPA method 1600 (U.S. Environmental Protection Agency, 2002c). Samples collected by the USGS for fecal coliform determinations were kept on ice and shipped overnight to the USGS Ohio Water Microbiology Laboratory (OWML) for analysis.

Table 2. Constituent name, U.S. Geological Survey National Water Information System parameter codes, and minimum reporting limits for temperature, specific conductance, dissolved oxygen, $\mathrm{pH}$, nutrients, and dissolved organic carbon.

$\left[{ }^{\circ} \mathrm{C}\right.$, degrees Celsius; na, not applicable; $\mu \mathrm{S} / \mathrm{cm}$, microsiemens per centimeter; $\mathrm{mg} / \mathrm{L}$, milligrams per liter; N, nitrogen; $\mathrm{P}$, phosphorus]

\begin{tabular}{clc}
\hline $\begin{array}{c}\text { Parameter } \\
\text { code }\end{array}$ & \multicolumn{1}{c}{ Constituent name } & $\begin{array}{c}\text { Minimum or } \\
\text { laboratory } \\
\text { reporting limit }\end{array}$ \\
\hline 00010 & Temperature, water $\left({ }^{\circ} \mathrm{C}\right)$ & 0.1 \\
00095 & Specific conductance, field $\left(\mu \mathrm{S} / \mathrm{cm}\right.$ at $\left.25^{\circ} \mathrm{C}\right)$ & 1.0 \\
00300 & Oxygen, dissolved $(\mathrm{mg} / \mathrm{L})$ & 0.1 \\
00400 & pH, field, unfiltered water (standard units) & 0.01 \\
00613 & Nitrogen, nitrite, dissolved $(\mathrm{mg} / \mathrm{L}$ as $\mathrm{N})$ & 0.5 \\
00631 & Nitrogen, nitrite plus nitrate, dissolved $(\mathrm{mg} / \mathrm{L}$ as $\mathrm{N})$ & 0.05 \\
00608 & Nitrogen, ammonia, dissolved (mg/L as $\mathrm{N})$ & 0.01 \\
62854 & Nitrogen, total, dissolved $(\mathrm{mg} / \mathrm{L})$ & \\
62855 & Nitrogen, total, unfiltered $(\mathrm{mg} / \mathrm{L}$ as N) & 0.006 \\
00671 & Phosphorus, orthophosphate, dissolved $(\mathrm{mg} / \mathrm{L}$ as $\mathrm{P})$ & 0.001 \\
00665 & Phosphorus, total $(\mathrm{mg} / \mathrm{L}$ as $\mathrm{P})$ & 0.5 \\
00681 & Carbon, organic, dissolved $(\mathrm{mg} / \mathrm{L})$ & \\
\hline
\end{tabular}




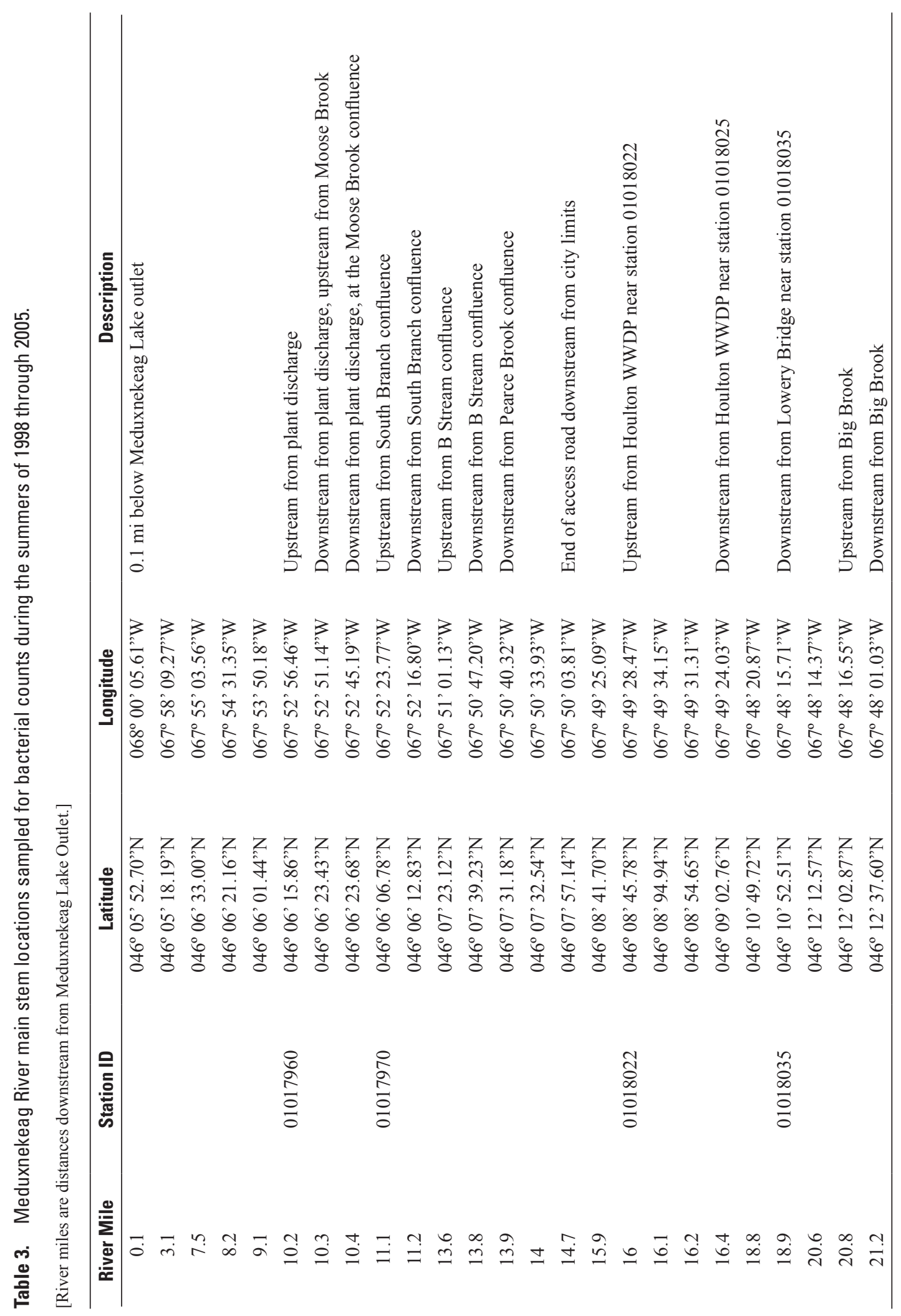




\section{Bacterial-Source Analysis and Identification}

Forty-four water samples collected from June through September 2005 for bacterial-source identification were sent to the OWML for enumeration of somatic coliphage; enumeration and isolation of $\mathrm{F}$-specific ribonucleic acid (RNA) coliphage; enumeration and enrichment of Enterococci; detection of the human-associated esp marker in Enterococcus faecium; and detection of general fecal (Bac32), humanassociated (HF134 and HF183), and ruminant-associated (CF128 and CF193) markers in anaerobic gut bacteria of the order Bacteroidales. The techniques and methods used in microbial-source tracking have been previously described (Stoeckel, 2005). In this study, coliphage were enumerated as an alternate indicator of fecal contamination according to USEPA method 1602 (U.S. Environmental Protection Agency, 2001). The goal of analyzing for coliphage was to type the virus into host-associated classes (as in Hsu and others, 1995); however, insufficient coliphage were isolated to justify anything more than a preliminary classification. Enumeration of Enterococci was done on mEI agar according to USEPA method 1600 (U.S. Environmental Protection Agency, 2002c). Single filters that held 100 or more Enterococci colonies were enriched according to the procedure in Scott and others (2005). If 100 or more Enterococci colonies were not available on a single filter, all filters for that sample were combined to create a single enrichment, and the total number of colonies was recorded.

Deoxyribonucleic acid (DNA) from Enterococci enrichment cultures was extracted and tested by polymerase chain reaction (PCR) for the human-associated esp marker (Scott and others, 2005). For analysis of Bacteroidales-based host-associated markers, a 100-mL sample was filtered through a $0.45-\mu \mathrm{m}$ cellulose acetate filter. DNA was extracted from the filters with MoBio (Hayward, California) DNA extraction kits and quantified by a PicoGreen (Molecular Probes (Invitrogen), Carlsbad, Calif.) protocol. DNA extracts were tested for the presence of human-specific Bacteroides markers HF134 and HF183 and ruminant-specific Bacteroides markers CF128 and CF193 by using the protocols reported by Bernhard and Field (2000). Enumeration and sample stabilization (DNA extraction and freezing) were done on all samples. All samples for PCR analysis were separated and analyzed by an Agilent Bioanalyzer (Agilent Technologies, Inc., Santa Clara, Calif.). The 22 samples were analyzed as part of larger PCR runs that included other test samples and several types of quality-control samples. Matrix spikes were run in parallel with each environmental test sample by adding 1 microliter $(\mu \mathrm{L})$ of positive-control DNA for each reaction to the matrix-spike PCR master mix. In each case, the matrix spike showed detection of the target DNA.

\section{Physical, Chemical, and Nutrient Attributes}

Continuous water-quality parameters of water temperature, dissolved oxygen, $\mathrm{pH}$, and specific conductance were monitored during June through September 2005 at several sites on the Meduxnekeag River upstream and downstream from the town of Houlton and the Houlton WWDP. Several summer storm events occurred during this monitoring period and are compared.

Daily rainfall and temperature records were assembled from digital records maintained by the National Oceanic and Atmospheric Administration's National Climatic Data Center (NOAA-NCDC), 2005, for the weather station Houlton 5N Station ID 173944 at Houlton, Maine (elevation 118.9 m, latitude/longitude $46^{\circ} 12^{\prime} \mathrm{N} / 67^{\circ} 50^{\prime} \mathrm{W}$ ).

Stream-discharge data were obtained from USGS digital data files for Meduxnekeag River stations 01017960 (above South Branch; the most upstream station), 01018000 (at Houlton; historic station), and 01018035 (at Lowery Road the most downstream station).

\section{In Situ Characteristics}

Water-quality values measured by the in situ monitors upstream and downstream from the town of Houlton and the Houlton WWDP were consistent (table 4). The storms generating the largest runoff occurred in mid-June, midJuly, mid-August, and early and mid-September (monthly rainfall reports for Station ID 173944 at Houlton, Maine, from the National Oceanic and Atmospheric Administration, 2005; stream-discharge data from the USGS National Water Information System) (figs. 4A, B). Water temperature varied from a low of $12{ }^{\circ} \mathrm{C}$ following the storm in mid-June to a high of $30^{\circ} \mathrm{C}$ in mid-July and early August before gradually declining to about $12{ }^{\circ} \mathrm{C}$ at the end of September (fig. 5A).

Dissolved oxygen (DO) concentrations remained between about 7 and $12 \mathrm{mg} / \mathrm{L}$ at all three sites $(01017960,01018000$, and 01018035 ) throughout the season with diurnal variation in the range of 2 to $4 \mathrm{mg} / \mathrm{L}$ (fig. 5B). During periods of four to five days following the largest runoff events in late August and mid-September, diurnal variation in DO concentrations was reduced to less than $1 \mathrm{mg} / \mathrm{L}$. DO was generally lower at site 01017960 during most of the summer than at site 01018035 . During the periods of the summer when water temperature was warmest, July 17 to 24 and August 7 to 18 , dissolved oxygen was highest at site 01018035 (figs. 5A, B). There were moderate variations in $\mathrm{pH}$ among sites or over time (range $=7.3$ to 8.7$)$ with the greatest shifts $(\sim 0.5 \mathrm{pH}$ unit decrease $)$ occurring during the largest runoff events in late August and mid-September at all three sites (fig. 5C).

The biggest difference in water-quality parameters among sites was observed for specific conductance, which was substantially higher at site 01018035 than at sites 


\section{Water Quality and Sources of Fecal Coliform Bacteria in the Meduxnekeag River, Houlton, Maine}

Table 4. Water-quality sample results, Meduxnekeag River (and tributary inputs) near Houlton, Maine, 2005.

\begin{tabular}{|c|c|c|c|c|c|c|c|c|c|c|}
\hline $\begin{array}{c}\text { STAID } \\
\text { station } \\
\text { number }\end{array}$ & $\begin{array}{c}\text { River mile } \\
\text { (interpolated } \\
\text { geographi- } \\
\text { cally } \\
\text { along } \\
\text { Meduxnekeag } \\
\text { River from } \\
\text { site IDs } \\
\text { of Maliseet } \\
\text { sampling } \\
\text { sites) }\end{array}$ & Dates & $\begin{array}{c}\text { Times } \\
\text { sample } \\
\text { start } \\
\text { time }\end{array}$ & $\begin{array}{c}\text { P00061 } \\
\text { Dis- } \\
\text { charge, } \\
\text { instanta- } \\
\text { neous, } \\
\text { cubic } \\
\text { feet } \\
\text { per } \\
\text { second }\end{array}$ & $\begin{array}{c}\text { P00025 } \\
\text { Baro- } \\
\text { metric } \\
\text { pressure, } \\
\text { millime- } \\
\text { ters of } \\
\text { mercury }\end{array}$ & $\begin{array}{c}\text { P00300 } \\
\text { Dissolved } \\
\text { oxygen, } \\
\text { water, } \\
\text { unfil- } \\
\text { tered, } \\
\text { milli- } \\
\text { grams } \\
\text { per liter }\end{array}$ & $\begin{array}{c}\text { P00301 } \\
\text { Dissolved } \\
\text { oxygen, } \\
\text { water, } \\
\text { unfiltered, } \\
\text { percent } \\
\text { of } \\
\text { saturation }\end{array}$ & $\begin{array}{c}\text { P00400 } \\
\text { pH, } \\
\text { water, } \\
\text { unfil- } \\
\text { tered, } \\
\text { field, } \\
\text { standard } \\
\text { units }\end{array}$ & $\begin{array}{c}\text { P00095 } \\
\text { Specific } \\
\text { conductance, } \\
\text { water, } \\
\text { unfiltered, } \\
\text { microsiemens } \\
\text { per } \\
\text { centimeter } \\
\text { at } \\
25 \text { degrees } \\
\text { Celsius }\end{array}$ & $\begin{array}{c}\text { P00010 } \\
\text { Temperature, } \\
\text { water, } \\
\text { degrees } \\
\text { Celsius }\end{array}$ \\
\hline 01017960 & 10.2 & Jun 232005 & 1110 & 119 & 753 & 8.2 & 90 & 7.8 & 149 & 19.2 \\
\hline 01017960 & 10.2 & Aug 102005 & 1245 & 15 & 749 & 8.8 & 114 & 8.2 & 182 & 27.6 \\
\hline 01017960 & 10.2 & Sep 152005 & 1040 & 14 & 754 & 10.2 & 111 & 8 & 135 & 18.7 \\
\hline 01017968 & & Jun 232005 & 1545 & & 753 & 8.9 & 98 & 8 & 169 & 19.2 \\
\hline 01017970 & 11.1 & Aug 102005 & 1440 & & 750 & 8.8 & 117 & 8.5 & 192 & 29.1 \\
\hline 01017970 & 11.1 & Sep 152005 & 1210 & & 754 & 10.5 & 114 & 8.1 & 144 & 18.6 \\
\hline 01018000 & 11.4 & Jun 22005 & 1230 & 324 & 756 & 9.8 & 106 & 7.8 & 123 & 18.8 \\
\hline 01018000 & 11.4 & Jun 232005 & 0900 & 212 & 753 & 8.6 & 90 & 7.6 & 145 & 16.8 \\
\hline 01018000 & 11.4 & Jul 142005 & 1600 & 63 & 750 & 9.4 & 108 & 8.3 & 189 & 21.1 \\
\hline 01018000 & 11.4 & Aug 102005 & 1145 & 30 & 750 & 8.9 & 110 & 8.2 & 182 & 25.3 \\
\hline 01018000 & 11.4 & Aug 102005 & 1910 & 36 & & & & & & \\
\hline 01018000 & 11.4 & Aug 112005 & 0925 & 36 & & & & & & \\
\hline 01018000 & 11.4 & Aug 302005 & 0645 & 174 & & & & & & \\
\hline 01018000 & 11.4 & Aug 302005 & 0855 & 224 & & & & & & \\
\hline 01018000 & 11.4 & Aug 302005 & 1325 & 273 & & & & & & \\
\hline 01018000 & 11.4 & Aug 302005 & 1750 & 324 & & & & & & \\
\hline 01018000 & 11.4 & Aug 312005 & 1050 & 383 & & & & & & \\
\hline 01018000 & 11.4 & Aug 312005 & 1555 & 435 & & & & & & \\
\hline 01018000 & 11.4 & Sep 12005 & 0000 & 496 & & & & & & \\
\hline 01018000 & 11.4 & Sep 12005 & 0455 & 566 & & & & & & \\
\hline 01018000 & 11.4 & Sep 12005 & 1105 & 603 & & & & & & \\
\hline 01018000 & 11.4 & Sep 12005 & 1835 & 667 & & & & & & \\
\hline 01018000 & 11.4 & Sep 22005 & 0455 & 680 & & & & & & \\
\hline 01018000 & 11.4 & Sep 22005 & 1230 & 641 & & & & & & \\
\hline 01018000 & 11.4 & Sep 42005 & 0250 & 324 & & & & & & \\
\hline 01018000 & 11.4 & Sep 52005 & 1420 & 191 & & & & & & \\
\hline 01018000 & 11.4 & Sep 152005 & 1330 & 60 & 754 & 10.7 & 116 & 8.1 & 139 & 18.8 \\
\hline 01018000 & 11.4 & Sep 172005 & 1450 & 163 & & & & & & \\
\hline 01018000 & 11.4 & Sep 172005 & 1650 & 216 & & & & & & \\
\hline 01018000 & 11.4 & Sep 172005 & 1900 & 259 & & & & & & \\
\hline 01018000 & 11.4 & Sep 172005 & 2305 & 306 & & & & & & \\
\hline 01018000 & 11.4 & Sep 182005 & 0250 & 360 & & & & & & \\
\hline
\end{tabular}


Table 4. Water-quality sample results, Meduxnekeag River (and tributary inputs) near Houlton, Maine, 2005.

\begin{tabular}{|c|c|c|c|c|c|c|c|c|c|c|c|c|}
\hline $\begin{array}{l}\text { Remark } \\
\text { for } \\
\text { P00608 }\end{array}$ & $\begin{array}{c}\text { P00608 } \\
\text { Ammonia, } \\
\text { water, } \\
\text { filtered, } \\
\text { milligrams } \\
\text { per liter } \\
\text { as } \\
\text { nitrogen }\end{array}$ & $\begin{array}{c}\text { Remark } \\
\text { for P00631 }\end{array}$ & $\begin{array}{c}\text { P00631 } \\
\text { Nitrite plus } \\
\text { nitrate, } \\
\text { water, } \\
\text { filtered, mil- } \\
\text { ligrams per } \\
\text { liter } \\
\text { as } \\
\text { nitrogen }\end{array}$ & $\begin{array}{c}\text { Remark } \\
\text { for } \\
\text { P00613 }\end{array}$ & $\begin{array}{c}\text { P00613 } \\
\text { Nitrite, } \\
\text { water, } \\
\text { filtered, } \\
\text { milligrams } \\
\text { per liter } \\
\text { as } \\
\text { nitrogen }\end{array}$ & $\begin{array}{c}\text { Remark } \\
\text { for } \\
\text { P00671 }\end{array}$ & $\begin{array}{c}\text { P00671 } \\
\text { Ortho- } \\
\text { phosphate, } \\
\text { water, } \\
\text { filtered, } \\
\text { milligrams } \\
\text { per liter } \\
\text { as } \\
\text { phosphorus }\end{array}$ & $\begin{array}{c}\text { Remark } \\
\text { for } \\
\text { P00665 }\end{array}$ & $\begin{array}{c}\text { P00665 } \\
\text { Phosphorus, } \\
\text { water, } \\
\text { unfiltered, } \\
\text { milligrams } \\
\text { per liter }\end{array}$ & $\begin{array}{c}\text { P62854 } \\
\text { Total } \\
\text { nitrogen } \\
\text { (nitrate + } \\
\text { nitrite + } \\
\text { ammonia + } \\
\text { organic-N), } \\
\text { water, } \\
\text { filtered, } \\
\text { analytically } \\
\text { determined, } \\
\text { milligrams } \\
\text { per liter }\end{array}$ & $\begin{array}{c}\text { P62855 } \\
\text { Total } \\
\text { nitrogen } \\
\text { (nitrate + } \\
\text { nitrite + } \\
\text { ammonia + } \\
\text { organic-N), } \\
\text { water, } \\
\text { unfiltered, } \\
\text { analytically } \\
\text { determined, } \\
\text { milligrams } \\
\text { per liter }\end{array}$ & $\begin{array}{c}\text { P00681 } \\
\text { Organic } \\
\text { carbon, } \\
\text { water, } \\
\text { filtered, } \\
\text { milli- } \\
\text { grams } \\
\text { per liter }\end{array}$ \\
\hline$<$ & 0.04 & & 0.09 & $<$ & 0.008 & $<$ & 0.006 & & 0.01 & & 0.34 & 5.5 \\
\hline$<$ & 0.04 & $\mathrm{E}$ & 0.04 & $<$ & 0.008 & $<$ & 0.006 & & 0.007 & & 0.39 & \\
\hline$<$ & 0.04 & E & 0.06 & $<$ & 0.008 & $<$ & 0.006 & & & 0.33 & & \\
\hline \multirow[t]{2}{*}{$<$} & 0.04 & & 0.45 & $<$ & 0.008 & $<$ & 0.006 & & 0.013 & & 0.77 & 8.1 \\
\hline & & & & & & & & & 0.01 & & 0.49 & \\
\hline$<$ & 0.04 & & 0.16 & $<$ & 0.008 & $<$ & 0.006 & & & & 0.48 & \\
\hline$<$ & 0.04 & & 0.12 & $<$ & 0.008 & $<$ & 0.006 & & 0.009 & 0.36 & 0.39 & 7.1 \\
\hline \multirow[t]{2}{*}{$<$} & 0.04 & & 0.18 & $<$ & 0.008 & $<$ & 0.006 & & 0.012 & & 0.46 & 8 \\
\hline & & & & & & & & & 0.01 & & 0.47 & \\
\hline \multirow[t]{17}{*}{$<$} & 0.04 & & 0.23 & $<$ & 0.008 & $<$ & 0.006 & & 0.011 & & 0.57 & \\
\hline & & & & & & & & & 0.016 & & 0.68 & \\
\hline & & & & & & & & & 0.012 & & 0.54 & \\
\hline & & & & & & & & & 0.024 & & 0.76 & \\
\hline & & & & & & & & & 0.016 & & 0.64 & \\
\hline & & & & & & & & & 0.025 & & 0.62 & \\
\hline & & & & & & & & & 0.026 & & 0.52 & \\
\hline & & & & & & & & & 0.019 & & 0.47 & \\
\hline & & & & & & & & & 0.022 & & 0.46 & \\
\hline & & & & & & & & & 0.025 & & 0.52 & \\
\hline & & & & & & & & & 0.029 & & 0.56 & \\
\hline & & & & & & & & & 0.029 & & 0.59 & \\
\hline & & & & & & & & & 0.042 & & 0.58 & \\
\hline & & & & & & & & & 0.025 & & 0.57 & \\
\hline & & & & & & & & & 0.021 & & 0.54 & \\
\hline & & & & & & & & & 0.021 & & 0.67 & \\
\hline & & & & & & & & & 0.018 & & 0.6 & \\
\hline \multirow[t]{6}{*}{$<$} & 0.04 & & 0.2 & $<$ & 0.008 & $<$ & 0.006 & & & & 0.62 & \\
\hline & & & & & & & & & 0.015 & & 0.5 & \\
\hline & & & & & & & & & 0.014 & & 0.56 & \\
\hline & & & & & & & & & 0.018 & & 0.59 & \\
\hline & & & & & & & & & 0.021 & & 0.6 & \\
\hline & & & & & & & & & 0.02 & & 0.52 & \\
\hline
\end{tabular}


Table 4. Water-quality sample results, Meduxnekeag River (and tributary inputs) near Houlton, Maine, 2005.

\begin{tabular}{|c|c|c|c|c|c|c|c|c|c|c|}
\hline $\begin{array}{l}\text { STAID } \\
\text { station } \\
\text { number }\end{array}$ & $\begin{array}{l}\text { River mile } \\
\text { (interpolated } \\
\text { geographi- } \\
\text { cally } \\
\text { along } \\
\text { Meduxnekeag } \\
\text { River from } \\
\text { site IDs } \\
\text { of Maliseet } \\
\text { sampling } \\
\text { sites) }\end{array}$ & Dates & $\begin{array}{c}\text { Times } \\
\text { sample } \\
\text { start } \\
\text { time }\end{array}$ & $\begin{array}{c}\text { P00061 } \\
\text { Dis- } \\
\text { charge, } \\
\text { instanta- } \\
\text { neous, } \\
\text { cubic } \\
\text { feet } \\
\text { per } \\
\text { second }\end{array}$ & $\begin{array}{c}\text { P00025 } \\
\text { Baro- } \\
\text { metric } \\
\text { pressure, } \\
\text { millime- } \\
\text { ters of } \\
\text { mercury }\end{array}$ & $\begin{array}{c}\text { P00300 } \\
\text { Dissolved } \\
\text { oxygen, } \\
\text { water, } \\
\text { unfil- } \\
\text { tered, } \\
\text { milli- } \\
\text { grams } \\
\text { per liter }\end{array}$ & $\begin{array}{c}\text { P00301 } \\
\text { Dissolved } \\
\text { oxygen, } \\
\text { water, } \\
\text { unfiltered, } \\
\text { percent } \\
\text { of } \\
\text { saturation }\end{array}$ & $\begin{array}{c}\text { P00400 } \\
\text { pH, } \\
\text { water, } \\
\text { unfil- } \\
\text { tered, } \\
\text { field, } \\
\text { standard } \\
\text { units }\end{array}$ & $\begin{array}{c}\text { P00095 } \\
\text { Specific } \\
\text { conductance, } \\
\text { water, } \\
\text { unfiltered, } \\
\text { microsiemens } \\
\text { per } \\
\text { centimeter } \\
\text { at } \\
25 \text { degrees } \\
\text { Celsius }\end{array}$ & $\begin{array}{c}\text { P00010 } \\
\text { Temperature, } \\
\text { water, } \\
\text { degrees } \\
\text { Celsius }\end{array}$ \\
\hline 01018000 & 11.4 & Sep 182005 & 1900 & 419 & & & & & & \\
\hline 01018000 & 11.4 & Sep 202005 & 0135 & 343 & & & & & & \\
\hline 01018010 & & Aug 112005 & 1015 & & 749 & 8 & 92 & 7.4 & 280 & 21.5 \\
\hline 01018010 & & Sep 152005 & 0700 & & 755 & 9.9 & 104 & 7.6 & 162 & 17.2 \\
\hline 01018012 & & Aug 112005 & 1000 & & 749 & 8.7 & 97 & 7.5 & 335 & 19.9 \\
\hline 01018012 & & Sep 152005 & 1500 & & 755 & 10 & 104 & 8 & 373 & 16.8 \\
\hline 01018014 & & Jul 142005 & 1620 & & & & & & & \\
\hline 01018014 & & Aug 102005 & 1745 & 0.07 & & & & & & \\
\hline 01018014 & & Sep 152005 & 0815 & 0.05 & 755 & 14.7 & 147 & 8.1 & 832 & 14.7 \\
\hline 01018015 & 14.3 & Aug 112005 & 1030 & & 750 & 8.2 & 97 & 7.6 & 227 & 22.9 \\
\hline 01018022 & 16 & Jun 22005 & 1115 & & 756 & 10 & 104 & 7.9 & 136 & 16.7 \\
\hline 01018022 & 16 & Jul 142005 & 1345 & & 750 & 9.9 & 111 & 8.4 & 224 & 20 \\
\hline 01018022 & 16 & Aug 112005 & 1245 & & 750 & 8.8 & 109 & 8.1 & 241 & 25.1 \\
\hline 01018022 & 16 & Sep 142005 & 1700 & & 755 & 10.9 & 119 & 8.2 & 177 & 19.3 \\
\hline 01018025 & 16.4 & Jun 22005 & 1000 & & 755 & 9.8 & 100 & 7.8 & 143 & 15.7 \\
\hline 01018025 & 16.4 & Jun 22005 & 1115 & & & & & & & \\
\hline 01018025 & 16.4 & Aug 112005 & 1315 & & 750 & 9.3 & 115 & 8.2 & 262 & 25.2 \\
\hline 01018025 & 16.4 & Sep 142005 & 1600 & & 756 & 11.4 & 124 & 8.3 & 178 & 19.1 \\
\hline 01018030 & & Aug 112005 & 1345 & & 750 & 8.6 & 99 & 8.1 & 327 & 21.6 \\
\hline 01018035 & 18.9 & Jun 22005 & 0830 & & 756 & 9.6 & 96 & 7.7 & 156 & 14.8 \\
\hline 01018035 & 18.9 & Jul 142005 & 1230 & 99 & 750 & 9.5 & 107 & 8.3 & 247 & 20.1 \\
\hline 01018035 & 18.9 & Aug 102005 & 1645 & 44 & 750 & 9.5 & 127 & 8.7 & 260 & 29.5 \\
\hline 01018035 & 18.9 & Sep 142005 & 1330 & 55 & 756 & 11 & 116 & 8.2 & 194 & 17.7 \\
\hline 460624067523901 & & Aug 102005 & 1330 & 0.011 & 750 & 9.7 & 82 & 7.7 & 537 & 7.5 \\
\hline 460624067523901 & & Sep 152005 & 0930 & 0.011 & 755 & 10.5 & 88 & 7.3 & 550 & 7.3 \\
\hline
\end{tabular}


Table 4. Water-quality sample results, Meduxnekeag River (and tributary inputs) near Houlton, Maine, 2005.

\begin{tabular}{|c|c|c|c|c|c|c|c|c|c|c|c|c|}
\hline $\begin{array}{c}\text { Remark } \\
\text { for } \\
\text { P00608 }\end{array}$ & $\begin{array}{c}\text { P00608 } \\
\text { Ammonia, } \\
\text { water, } \\
\text { filtered, } \\
\text { milligrams } \\
\text { per liter } \\
\text { as } \\
\text { nitrogen }\end{array}$ & $\begin{array}{c}\text { Remark } \\
\text { for P00631 }\end{array}$ & $\begin{array}{c}\text { P00631 } \\
\text { Nitrite plus } \\
\text { nitrate, } \\
\text { water, } \\
\text { filtered, mil- } \\
\text { ligrams per } \\
\text { liter } \\
\text { as } \\
\text { nitrogen }\end{array}$ & $\begin{array}{c}\text { Remark } \\
\text { for } \\
\text { P00613 }\end{array}$ & $\begin{array}{c}\text { P00613 } \\
\text { Nitrite, } \\
\text { water, } \\
\text { filtered, } \\
\text { milligrams } \\
\text { per liter } \\
\text { as } \\
\text { nitrogen }\end{array}$ & $\begin{array}{c}\text { Remark } \\
\text { for } \\
\text { P00671 }\end{array}$ & $\begin{array}{c}\text { P00671 } \\
\text { Ortho- } \\
\text { phosphate, } \\
\text { water, } \\
\text { filtered, } \\
\text { milligrams } \\
\text { per liter } \\
\text { as } \\
\text { phosphorus }\end{array}$ & $\begin{array}{c}\text { Remark } \\
\text { for } \\
\text { P00665 }\end{array}$ & $\begin{array}{c}\text { P00665 } \\
\text { Phosphorus, } \\
\text { water, } \\
\text { unfiltered, } \\
\text { milligrams } \\
\text { per liter }\end{array}$ & $\begin{array}{c}\text { P62854 } \\
\text { Total } \\
\text { nitrogen } \\
\text { (nitrate + } \\
\text { nitrite + } \\
\text { ammonia + } \\
\text { organic-N), } \\
\text { water, } \\
\text { filtered, } \\
\text { analytically } \\
\text { determined, } \\
\text { milligrams } \\
\text { per liter }\end{array}$ & $\begin{array}{c}\text { P62855 } \\
\text { Total } \\
\text { nitrogen } \\
\text { (nitrate + } \\
\text { nitrite + } \\
\text { ammonia + } \\
\text { organic-N), } \\
\text { water, } \\
\text { unfiltered, } \\
\text { analytically } \\
\text { determined, } \\
\text { milligrams } \\
\text { per liter }\end{array}$ & $\begin{array}{c}\text { P00681 } \\
\text { Organic } \\
\text { carbon, } \\
\text { water, } \\
\text { filtered, } \\
\text { milli- } \\
\text { grams } \\
\text { per liter }\end{array}$ \\
\hline & & & & & & & & & 0.02 & & 0.5 & \\
\hline & & & & & & & & & 0.017 & & 0.52 & \\
\hline & & & & & & & & & 0.005 & & 0.92 & \\
\hline \multirow[t]{2}{*}{$<$} & 0.04 & & 0.34 & $<$ & 0.008 & $<$ & 0.006 & & & & 0.58 & \\
\hline & & & & & & & & & 0.031 & & 0.59 & \\
\hline \multirow[t]{2}{*}{$<$} & 0.04 & & 0.26 & $<$ & 0.008 & $<$ & 0.006 & & & 0.54 & & \\
\hline & & & & & & & & & 0.005 & & 2.14 & \\
\hline$<$ & 0.04 & & 2.37 & $\mathrm{E}$ & 0.004 & $<$ & 0.006 & & & & 2.49 & \\
\hline$<$ & 0.04 & & 0.33 & $<$ & 0.008 & $<$ & 0.006 & & 0.011 & & 0.65 & \\
\hline$<$ & 0.04 & & 0.14 & $<$ & 0.008 & $<$ & 0.006 & & 0.009 & & 0.39 & \\
\hline$<$ & 0.04 & & 0.16 & $<$ & 0.008 & $<$ & 0.006 & & 0.009 & & 0.55 & \\
\hline$<$ & 0.04 & & 0.32 & $<$ & 0.008 & $<$ & 0.006 & & 0.011 & & 0.62 & \\
\hline$<$ & 0.04 & & 0.23 & $<$ & 0.008 & $<$ & 0.006 & & & & 0.56 & \\
\hline \multirow[t]{2}{*}{$<$} & 0.04 & & 0.2 & $<$ & 0.008 & $<$ & 0.006 & & 0.01 & & 0.45 & 6.9 \\
\hline & & & & & & & & & & & & 6.6 \\
\hline$<$ & 0.04 & & 0.7 & $<$ & 0.008 & $<$ & 0.006 & & 0.012 & & 1.07 & \\
\hline \multirow[t]{2}{*}{$<$} & 0.04 & & 0.24 & $<$ & 0.008 & $<$ & 0.006 & & & & 0.58 & \\
\hline & & & & & & & & & 0.02 & & 0.66 & \\
\hline$<$ & 0.04 & & 0.23 & $<$ & 0.008 & $<$ & 0.006 & & 0.012 & & 0.52 & 6.4 \\
\hline$<$ & 0.04 & & 0.37 & $<$ & 0.008 & $<$ & 0.006 & & 0.01 & & 0.74 & 5 \\
\hline$<$ & 0.04 & & 0.59 & $\mathrm{E}$ & 0.004 & $<$ & 0.006 & & 0.011 & & 0.94 & \\
\hline \multirow[t]{2}{*}{$<$} & 0.04 & & 0.45 & $<$ & 0.008 & $<$ & 0.006 & & & & 0.78 & \\
\hline & & & & & & & & $<$ & 0.004 & & 13.9 & \\
\hline$<$ & 0.04 & & 13.3 & $<$ & 0.008 & $<$ & 0.006 & & & & 14.1 & \\
\hline
\end{tabular}



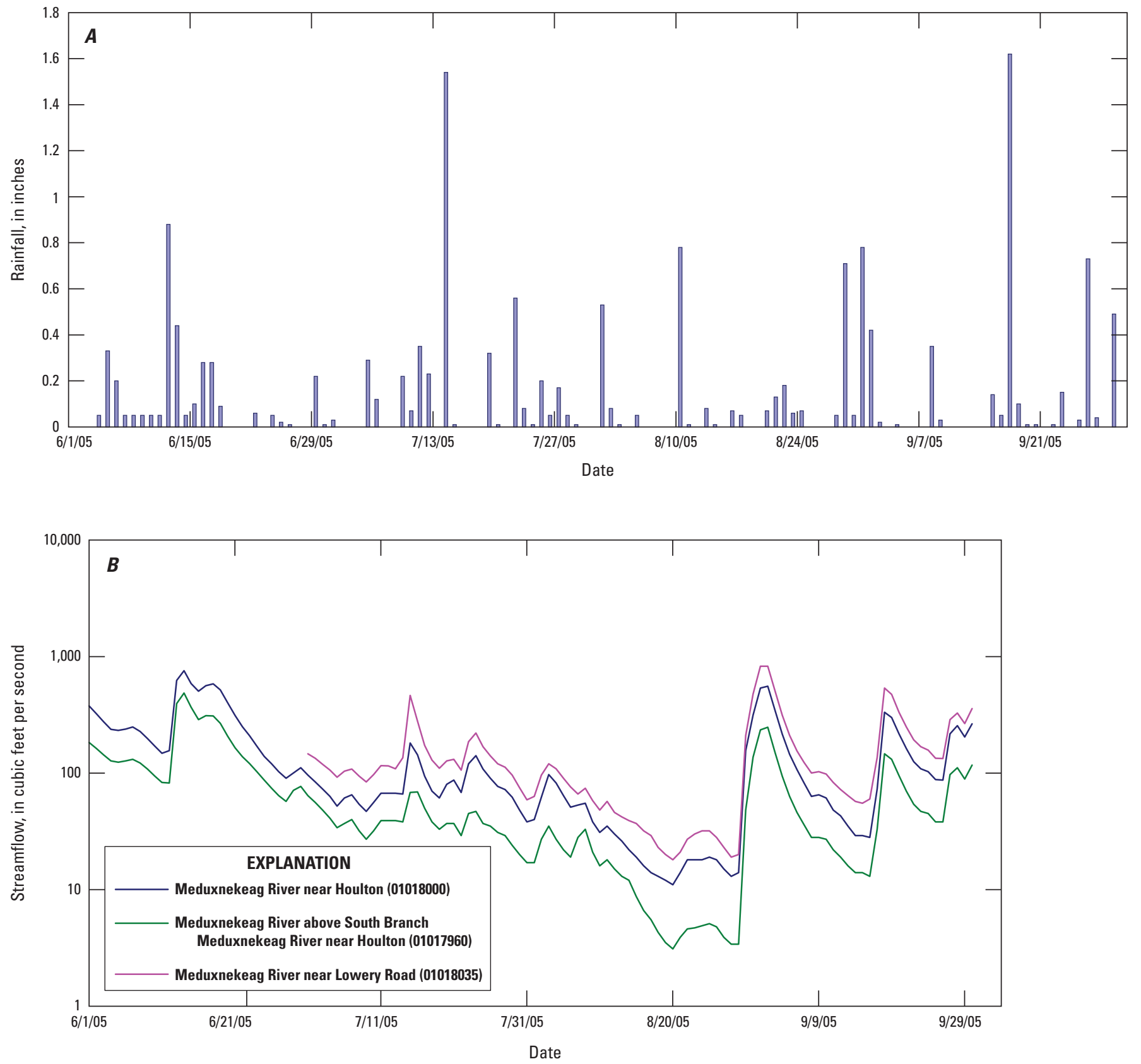

Figure 4. A, daily precipitation from June 1 through September 30, 2005, $B$, streamflow for the Meduxnekeag River at three sites near Houlton, Maine, from June through September 2005. 


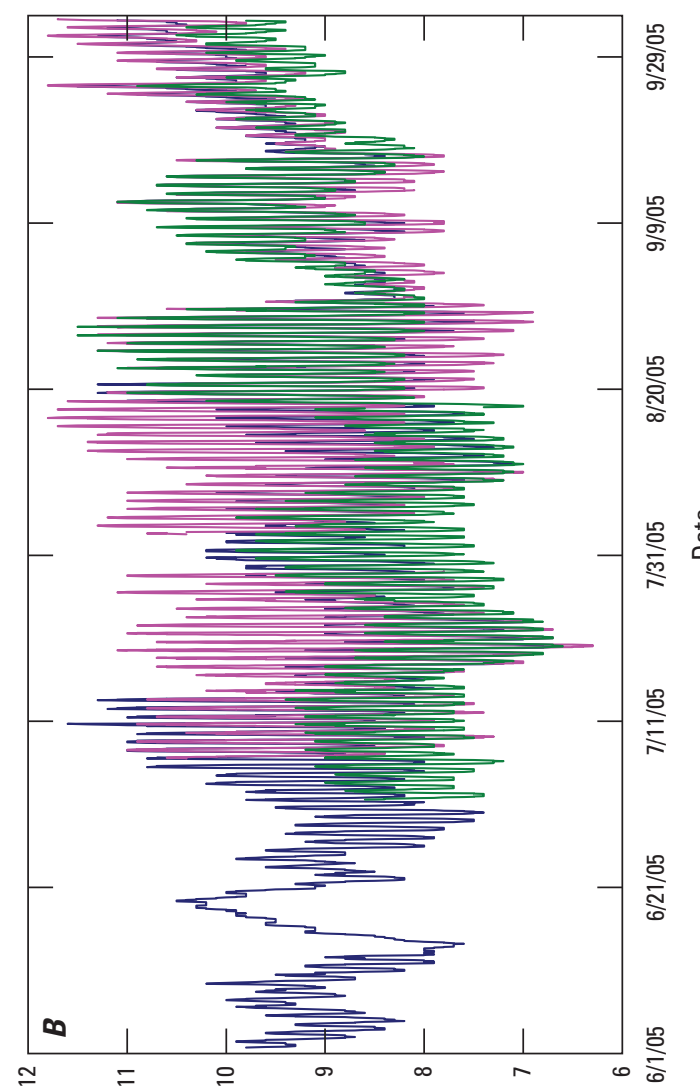

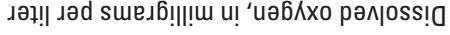

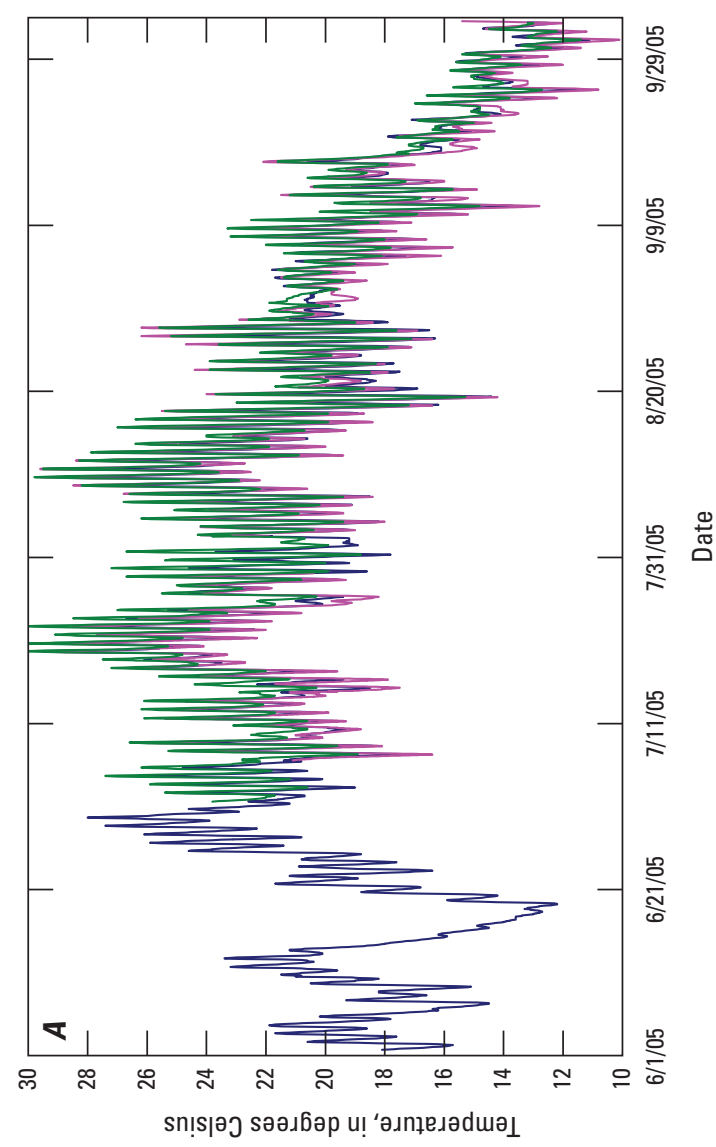

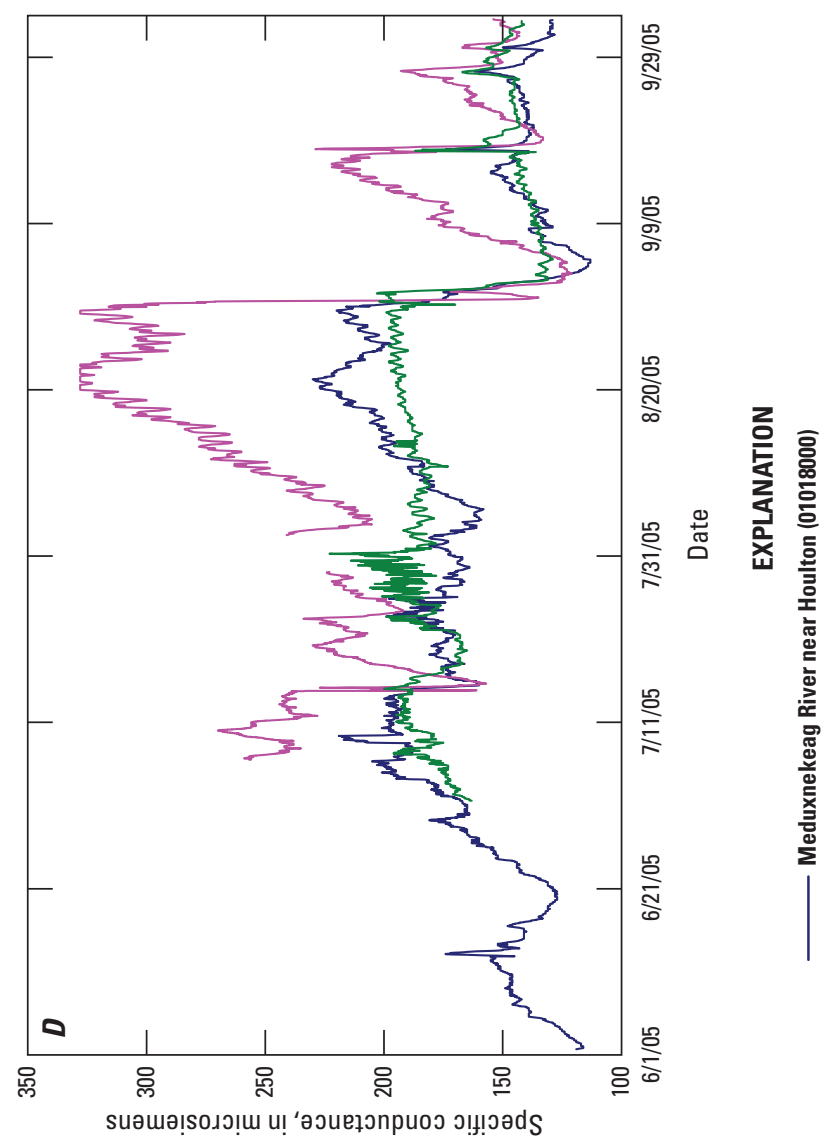

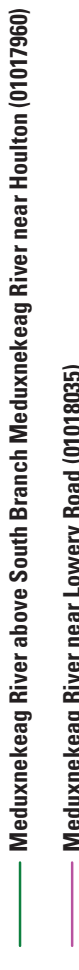

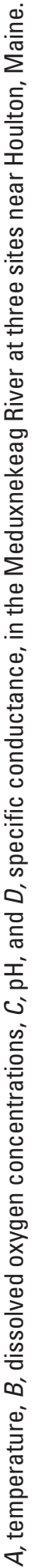

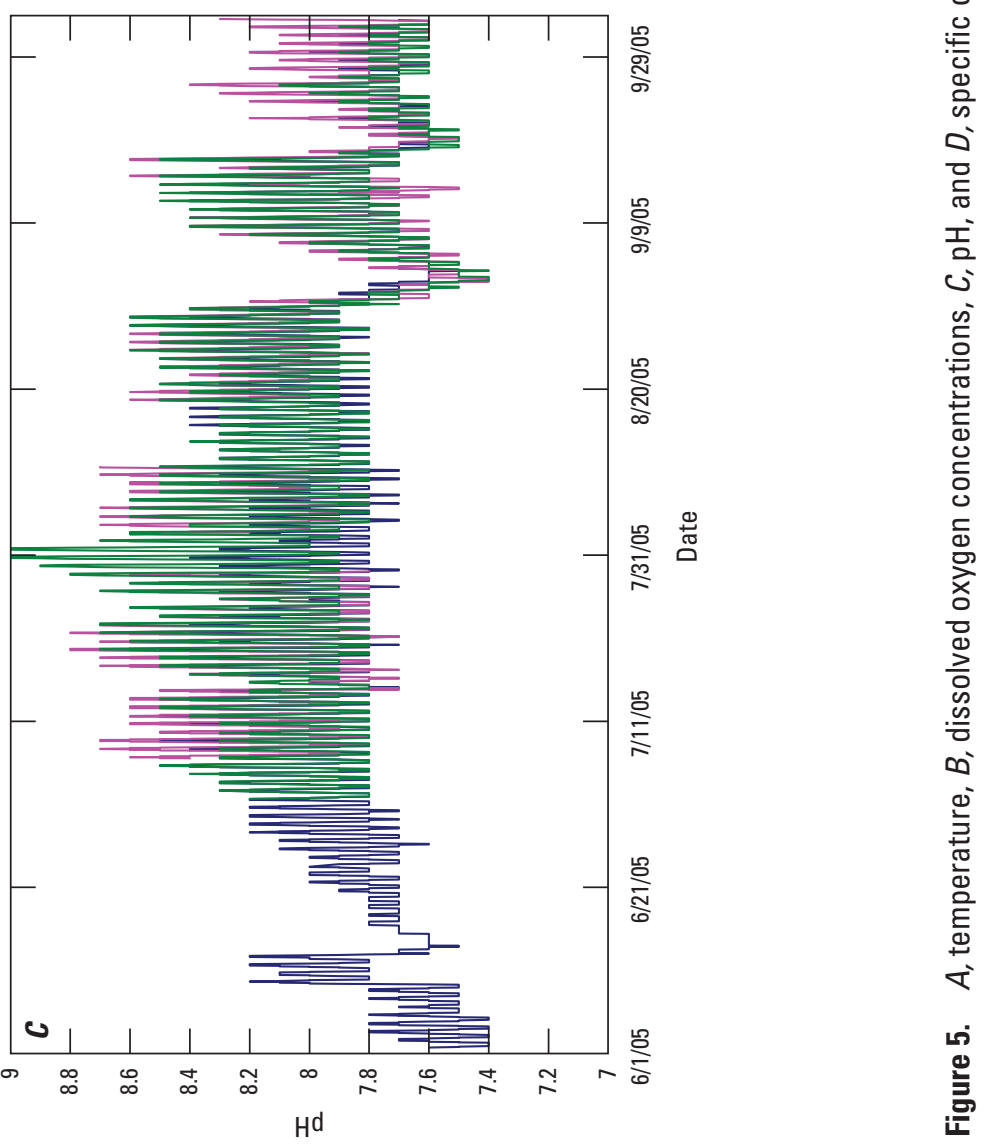


01017960 and 01018000 (fig. 5D). Specific conductance at site 01018035 also varied over the widest range from 123 to 328 microsiemens per centimeter $(\mu \mathrm{S} / \mathrm{cm})$. Specific conductance increased gradually at all three sites as streamflows declined (from August 4 to 19) and decreased rapidly during major runoff events (for example, August 30 to September 5). Absolute increases in specific conductance during periods of declining flows were greatest at site 01018035 , intermediate at site 01018000 , and least at site 01017960 (fig. 5D).

Few differences were observed between water-quality values continuously measured immediately above (01018022) and below (01018025) the Houlton WWDP (fig. 6). Specific conductance was somewhat higher (by less than 10 percent) downstream from the WWDP in August until the major runoff event, during and after which specific conductance was similar at these two sites (fig. 6). For the period of overlapping record in August 2005 prior to the runoff event, specific conductance upstream and downstream from the WWDP was consistently higher than it was at 01018000 (figs. 5D, 6) and about the same as that at 01018035 . Specific conductance increased more between sites 01017960 and 01018022 than it did between sites 01018022 and 01018035 ; specific conductance at site 01018022 immediately upstream from the WWDP differs by only 10 percent or less from the specific conductance at sites 01018025 and 01018035 .

\section{Discrete Nutrient Characteristics}

In addition to routine nutrient sampling, event-oriented nutrient sampling of phosphorus and nitrogen was conducted during the summer of 2005, and results were compared. Total phosphorus concentrations were low and fairly constant (range $=0.01$ to $0.015 \mathrm{mg} / \mathrm{L}$ ) during June through the beginning of August in samples collected at site 01018000, even after a storm event on June 2, 2005, when the streamflow was greater than 300 cubic feet per second $\left(\mathrm{ft}^{3} / \mathrm{s}\right.$ ) (fig.7, table 4). Waterquality samples were collected during periods of increased streamflow associated with two late summer storms that occurred from August 30 to September 7 and from September 17 to September 22, 2005. Average daily streamflow reached $556 \mathrm{ft}^{3} / \mathrm{s}$ during the first storm and concentrations of total phosphorus varied from 0.019 to $0.042 \mathrm{mg} / \mathrm{L}$. Average daily

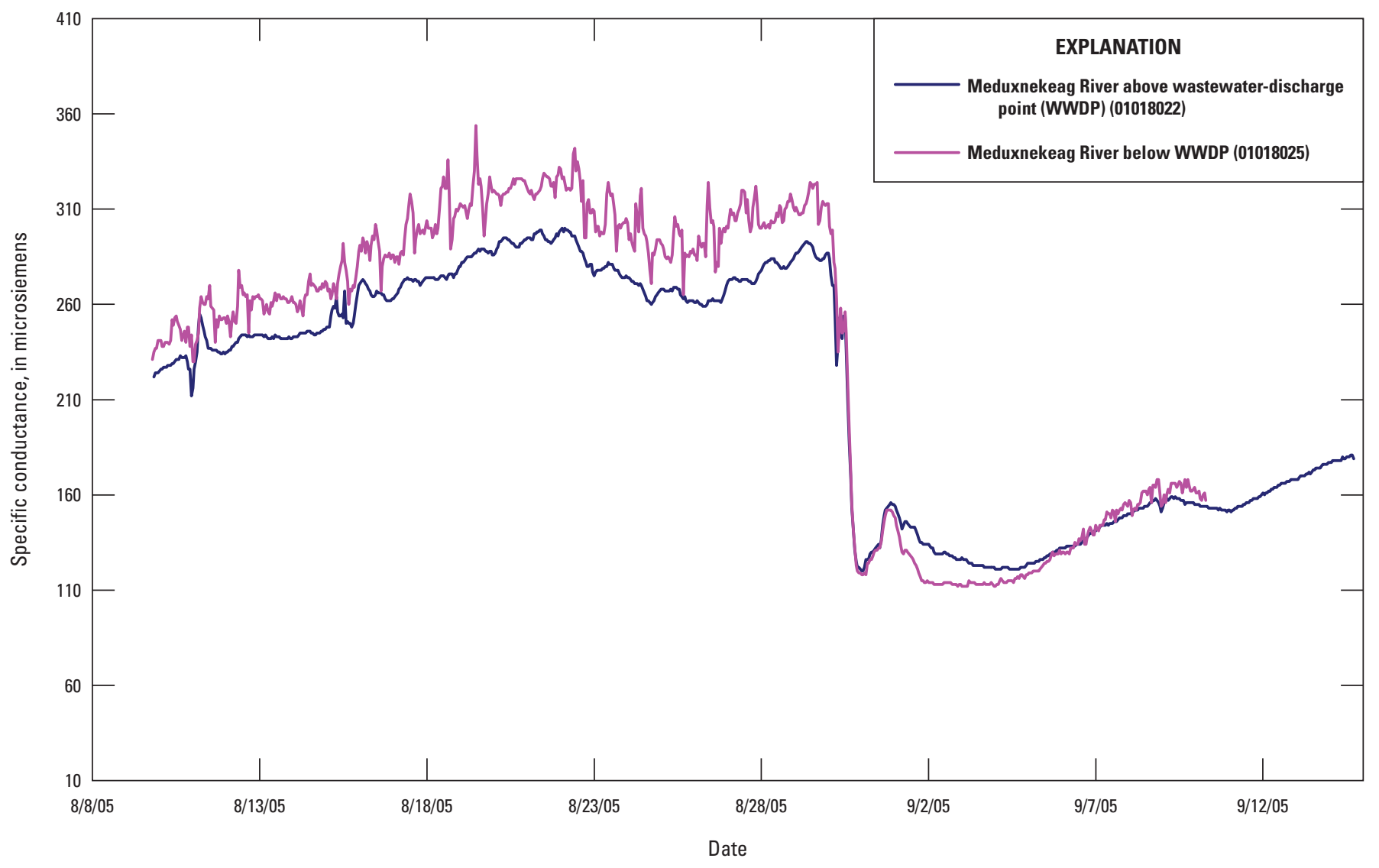

Figure 6. Specific conductance in the Meduxnekeag River upstream of the Houlton Wastewater Treatment Plant (01018022) and downstream of the Houlton Wastewater Treatment Plant (01018025) near Houlton, Maine, from August through September 2005. 


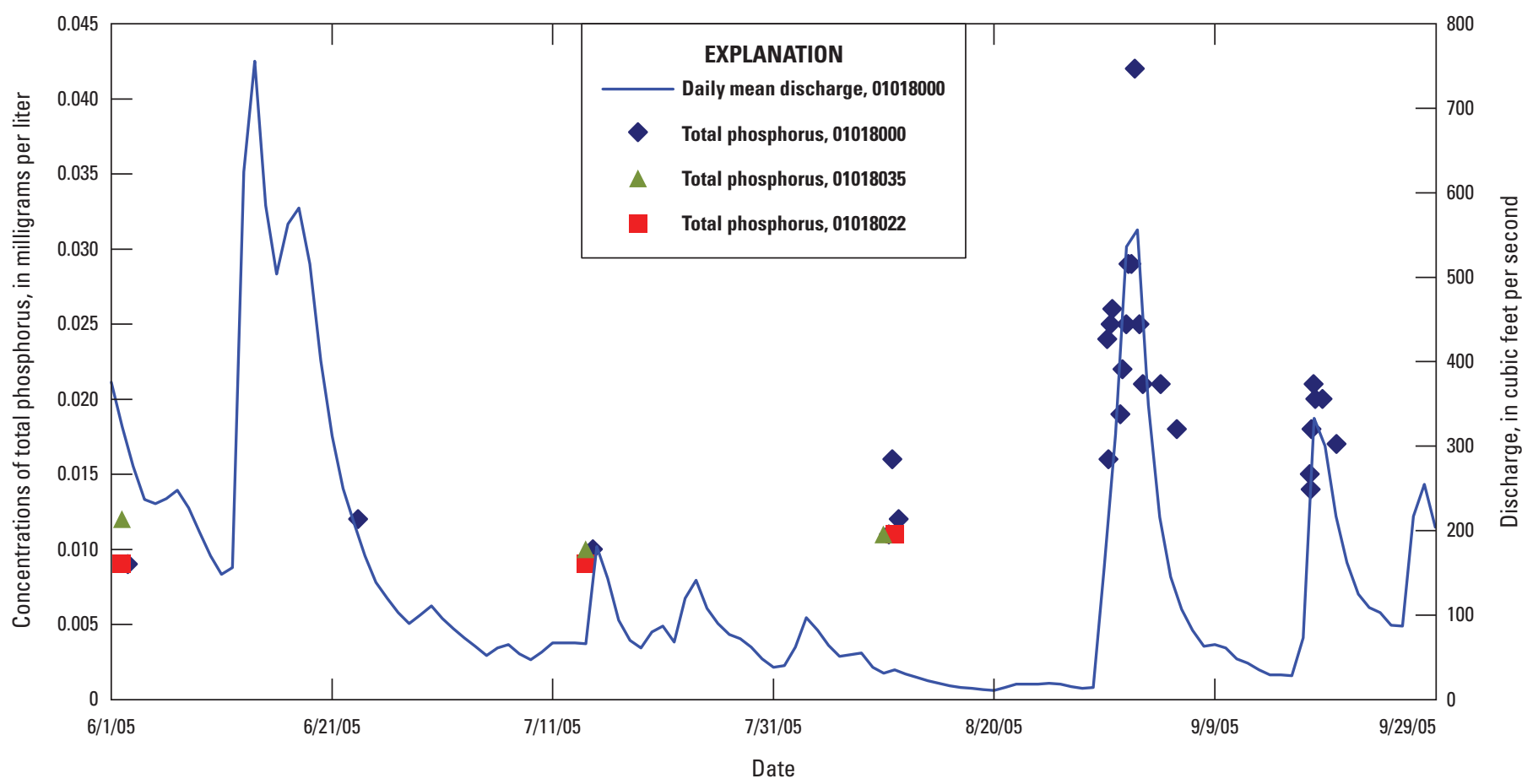

Figure 7. Total phosphorus measured in discrete samples collected at the three streamgages 01018000,01018022 , and 01018035 from June through September 2005.

streamflow reached $333 \mathrm{ft}^{3} / \mathrm{s}$ during the second storm and concentrations of total phosphorus varied from 0.012 to $0.021 \mathrm{mg} / \mathrm{L}$ (fig. 7). These data indicate a seasonal positive concentration-streamflow relation for total phosphorus. Concentrations of total phosphorus did not vary consistently through time or with increasing drainage area for sites 01018000, 01018022 , and 01018035 (fig. 7). The majority of the phosphorus was in the orthophosphate fraction (table 4).

Total nitrogen concentrations followed a pattern similar to the pattern for total phosphorus (figs. 7-8). Total nitrogen concentrations were fairly constant, in the range of 0.39 to $0.47 \mathrm{mg} / \mathrm{L}$, during June through mid-July and increased from 0.52 to $0.76 \mathrm{mg} / \mathrm{L}$ at site 01018000 during the two late summer storms. The relatively high concentrations of total nitrogen recorded for August 10 and 11 were not associated with a runoff event. Concentrations of total nitrogen in the Meduxnekeag River tended to increase from June through August and to increase more with increasing drainage area (fig. 8). For station 01018000 , concentrations of total nitrogen increased between 31 and 57 percent from June through September. Concentrations of total nitrogen were higher at site 01018035 than at sites 01018000 and 01018022 . In almost all samples, minimal concentrations of nitrate, nitrite, or ammonium were detected, indicating that organic nitrogen was the dominant form of nitrogen in the system (table 4).

\section{Distribution and Source of Fecal Indicator Bacteria}

Samples for analysis of fecal indicator bacteria were collected by the HBMI from 1998 through 2005 in a twentymile reach of the Meduxnekeag River above and below the town of Houlton and the Houlton WWDP. Samples for fecal indicator bacteria distribution and source were collected by the USGS in 2005 in a 10-mile section of the river above and below the town of Houlton and the Houlton WWDP.

\section{Fecal-Indicator Bacterial Densities}

Fecal-indicator bacterial densities were measured by HBMI in samples collected over several different time intervals from 1998 through 2005. Median fecal coliform bacterial densities increased from 31 to 64 fecal coliform bacterial colonies per $100 \mathrm{~mL}$ between sites RM 10.2 (where RM indicates river mile) and RM 14.7 for data collected in 1998 and 2005 (fig. 9A). On the basis of these data, fecal coliform contamination appears to originate primarily from sources between these two sites along the Meduxnekeag River. Bacterial densities increased from RM 14.7 to RM 16.4 (immediately downstream from the Houlton WWDP) (fig. 9A) and then declined farther downstream between RM 16.4 and 


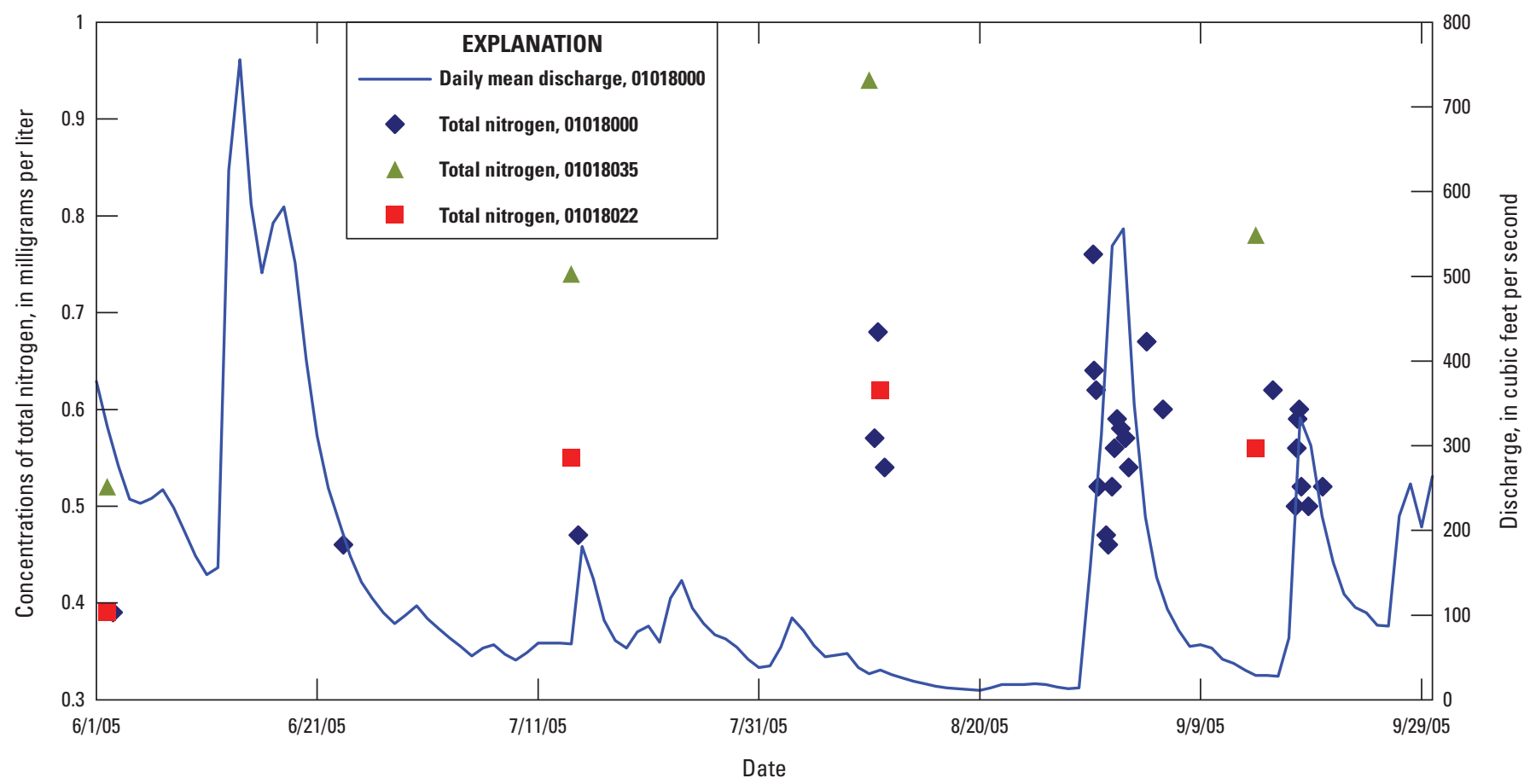

figure 8. Total nitrogen concentrations measured in discrete samples collected at the three streamgages 01018000, 01018022, and 01018035 from June through September 2005.

18.9 (fig. 9A). The pattern of bacterial contamination in the Meduxnekeag River indicates that the WWDP likely did not contribute substantially to measured bacterial densities (fig. 9A). Declines in fecal coliform bacterial contamination downstream likely resulted from (1) attenuation due to biological (for example, zooplankton grazing) and physical (for example, adsorption to sediments) processes, and (or) (2) from dilution by surface water and groundwater influxes that are less contaminated with fecal coliform bacteria. Bacterial densities measured at RM 10.2 and RM 11.2 during the period 1998-99 (fig. 9B) indicate that the South Branch likely contributed a substantial amount of the increase in bacterial densities between RMs 10.2 and 14.7 (fig. 9A). Further evidence for the South Branch having been a source of bacterial contamination comes from data collected during the period 2003-5 from sites RM 10.2, RM 11.1, RM 14.7, and RM 16.4 (fig. 9C). During this period, there was no significant difference in median bacterial densities between RM 10.2 and RM 11.1, but the median doubled between RM 11.1 and RM 14.7 (fig. 9C). Finally, medians of bacterial densities measured in samples from RM 14.7 and from the South Branch itself near the confluence with the Meduxnekeag River for the period 1999-2004 were about twice as high as in samples from RM 10.2 (fig. 9D).

Fecal coliform densities measured in samples collected from June through September 2001 from tributaries to the Meduxnekeag River yielded consistent results. When upstream and downstream samples were collected on a specific tributary during that period, fecal coliform densities were usually higher at downstream sites (those closer to the confluence with the Meduxnekeag River) than at upstream sites (fig. 10). The exceptions were Cook Brook and Jimmy Brook, where fecal coliform densities were higher in upstream than in downstream samples. Notably, there is an airport in the upper part of the Cook Brook watershed. Differences in land cover between upstream and downstream parts of watersheds might also be a factor. ${ }^{3}$ Forested land, a predominant land cover in the upper parts of the basins, may contribute fewer fecal coliform bacteria than agricultural or developed land in the lower parts of the basins; this may be the case for Pearce Brook, Smith Brook, Big Brook, B Stream, and Moose Brook watersheds (figs. 1, 3).

Clark and Gamper (2003) found that fecal-indicator bacteria densities were related to land cover in a study of the Wind River, Bighorn River, and Goose Creek basins in Wyoming. In their study, the highest median densities of fecalindicator bacteria were measured in samples from sites with an urban land cover, intermediate densities were associated with agricultural land cover, and the lowest densities were associated with forested sites. Lower Pearce Brook stands out as having higher fecal coliform densities than other parts

\footnotetext{
${ }^{3}$ Land-cover data for the extreme eastern parts of the Cook Brook and Smith Brook watersheds in Canada were not available for illustration in fig. 3 .
} 

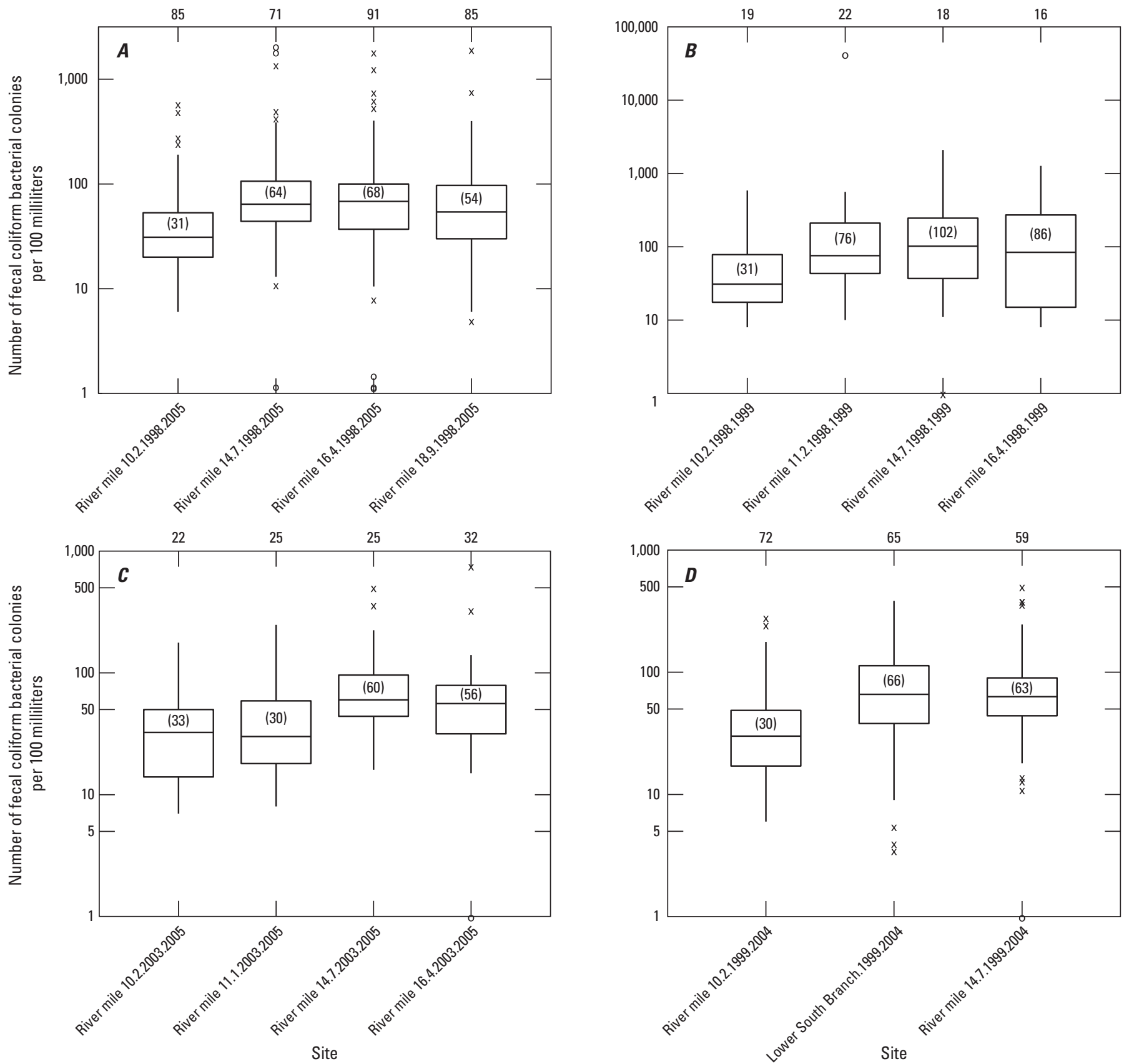

EXPLANATION

Number of values

Upper detached

Upper outside

Upper adjacent

Figure 9. Bacterial counts (fecal-coliform colonies per 100 milliliters $[\mathrm{mL}]$ ) in surfacewater samples collected during the summers of indicated years at selected sites on the Meduxnekeag River and on the South Branch of the Meduxnekeag River: $A, 1998-2005$ at 10.2, 14.7, 16.4, and 18.9 river miles below the Meduxnekeag Lake outlet; $B, 1998-1999$ at 10.2, 11.2, 14.7, and 16.4 river miles below the Meduxnekeag Lake outlet; $C, 2003-2005$ at 10.2, 11.1, 14.7, and 16.4 river miles below the Meduxnekeag Lake outlet; and $D$, 1999-2004 at 10.2 and 14.7 river miles below the Meduxnekeag Lake outlet and on the South Branch of the Meduxnekeag River near the confluence with the Meduxnekeag River.

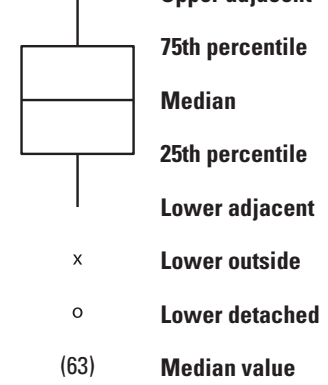


of tributaries, including upper Pearce Brook (fig. 10). Most of the area of the town of Houlton and a substantial amount of agricultural land is in the lower part of the Pearce Brook drainage basin (fig. 1, 3). The upper Pearce Brook drainage basin includes agricultural land in the southeastern part and forest and wetlands in the southwestern part (fig. 3). The fact that lower Big Brook did not have higher fecal coliform bacterial densities than some other tributaries is somewhat surprising given the predominance of agricultural land in the Big Brook drainage basin.

Specific conductance increased from site 01018000 to site 01018025 and remained high downstream from that point (01018035) (figs. 5D, 6), but fecal coliform bacterial densities peaked at the urban site near downtown Houlton (RM 14.7) and immediately downstream from the Houlton WWDP (RM 16.4) and decreased consistently downstream from that point to RM 18.9 at the Lowery Road Bridge near 01018035 (fig. 9A). This result suggests that the factors responsible for the increase in specific conductance are not closely related to those responsible for fecal coliform bacterial contamination in this reach of the Meduxnekeag River. Notably, Clark and Gamper (2003) also found that increased fecal-indicator bacterial densities were not related to specific conductance in three river basins in Wyoming.

The samples collected by the HBMI from 1998 through 2005 at RM 14.7 downstream from the urban area of Houlton had lower median fecal coliform bacterial densities than those collected on many rivers in Maine that were sampled as part of the USGS National Stream Quality Accounting Network program (Alexander and others, 1996) from 1976 through 1994 (fig. 11). Fecal coliform contamination was substantially higher in larger rivers having more development in areas upstream from sampling locations than in the Meduxnekeag River at RM 14.7 (fig. 11). For these other Maine rivers, as for the Meduxnekeag River and selected tributaries to the Meduxnekeag River, fecal coliform contamination

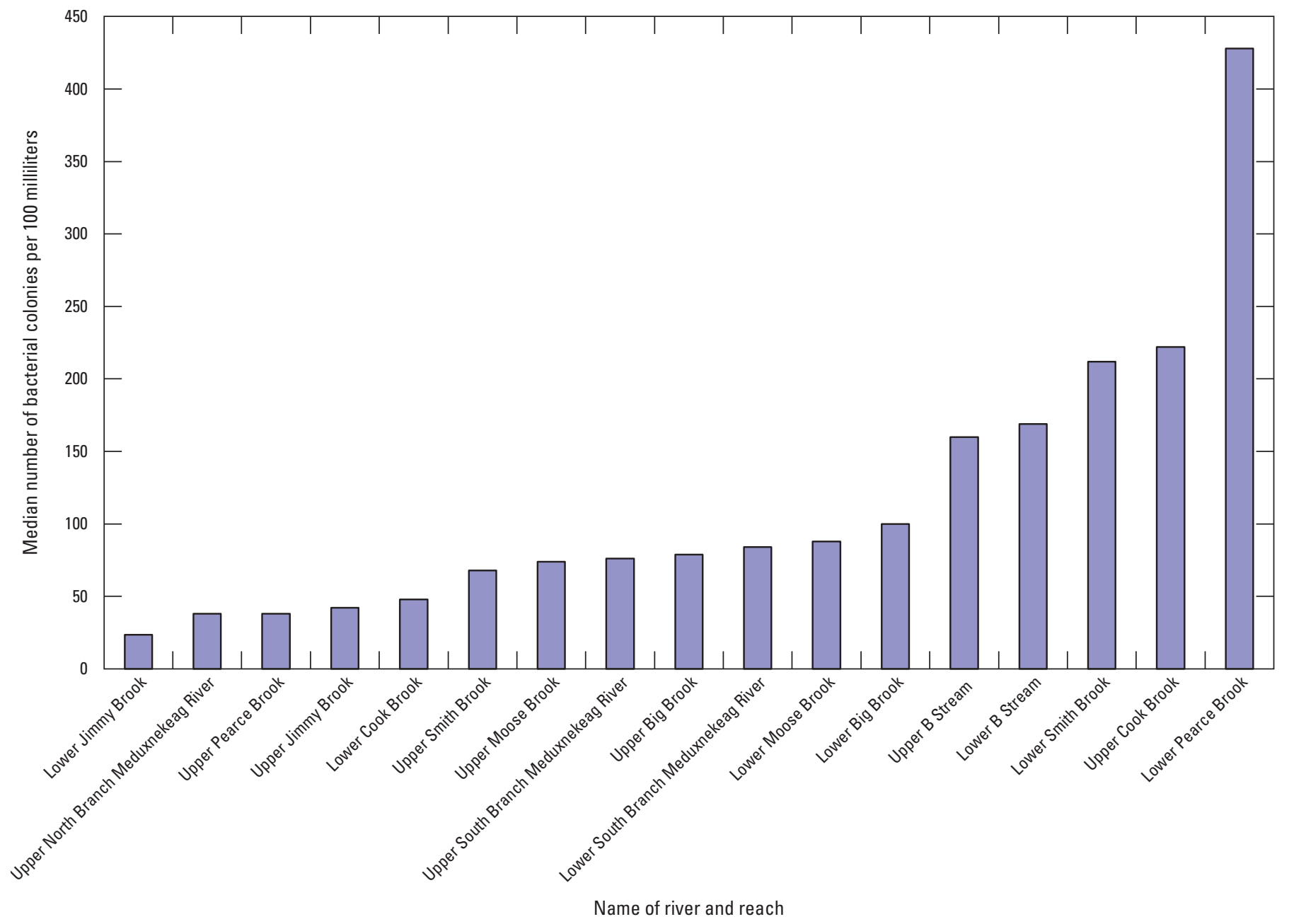

Figure 10. Medians of bacterial counts (fecal-coliform colonies per 100 milliliters $[\mathrm{mL}]$ ) in surface-water samples collected during the summer of 2001 at upstream and downstream sites on selected tributaries to the Meduxnekeag River near Houlton, Maine. 
increased from low levels in upstream locations (for example, at Bingham on the Kennebec River; and Gilead on the Wild River, which flows into the Androscoggin River) to substantially higher levels in downstream locations (fig. 11). Decreases in fecal coliform contamination in some major rivers in the United States (although not in Maine) from 1974 to 1981 were related to improvements in municipal wastewater treatment (Smith and Alexander, 1982; Smith and others, 1987).

\section{Bacterial-Source Identification}

According to the design of the study, 22 of 44 samples were tested for bacterial-source tracking (BST) markers; the remaining 22 samples were not tested based on low fecal coliform densities in the whole-water samples. Out of the 22 samples tested, 18 samples were selected based on (1) high fecal coliform densities in the whole-water sample, (2) a pattern of high fecal coliform densities at that particular site, or (3) a pattern of high fecal coliform densities on that date. In addition to the 18 environmental samples, 4 other samples were analyzed for BST: 1 field blank, 1 negative-control sample (horse reference feces from the study area), and 2 positive-control samples (cattle feces from the study area and a human-wastewater sample from the Houlton wastewatertreatment plant). Positive-control DNA samples from the Olentangy Environmental Control Center, Delaware, Ohio (a sewage influent sample for detection of Bac32 ${ }^{4}$ and humanspecific markers and a sample of cattle feces for detection of Bac32 and ruminant-specific markers) were included with each PCR run. The BST data were used to evaluate contamination patterns in the watershed.

The literature suggests that a mix of at least 100 colonies of Enterococci be tested for the human-associated esp gene (Scott and others, 2005; Whitman and others, 2007). Among the 22 samples tested, only 12 had Enterococci at sufficient

\footnotetext{
${ }^{4}$ Bac32 is a general fecal bacterial contamination DNA marker associated with the order Bacteroidales.
}

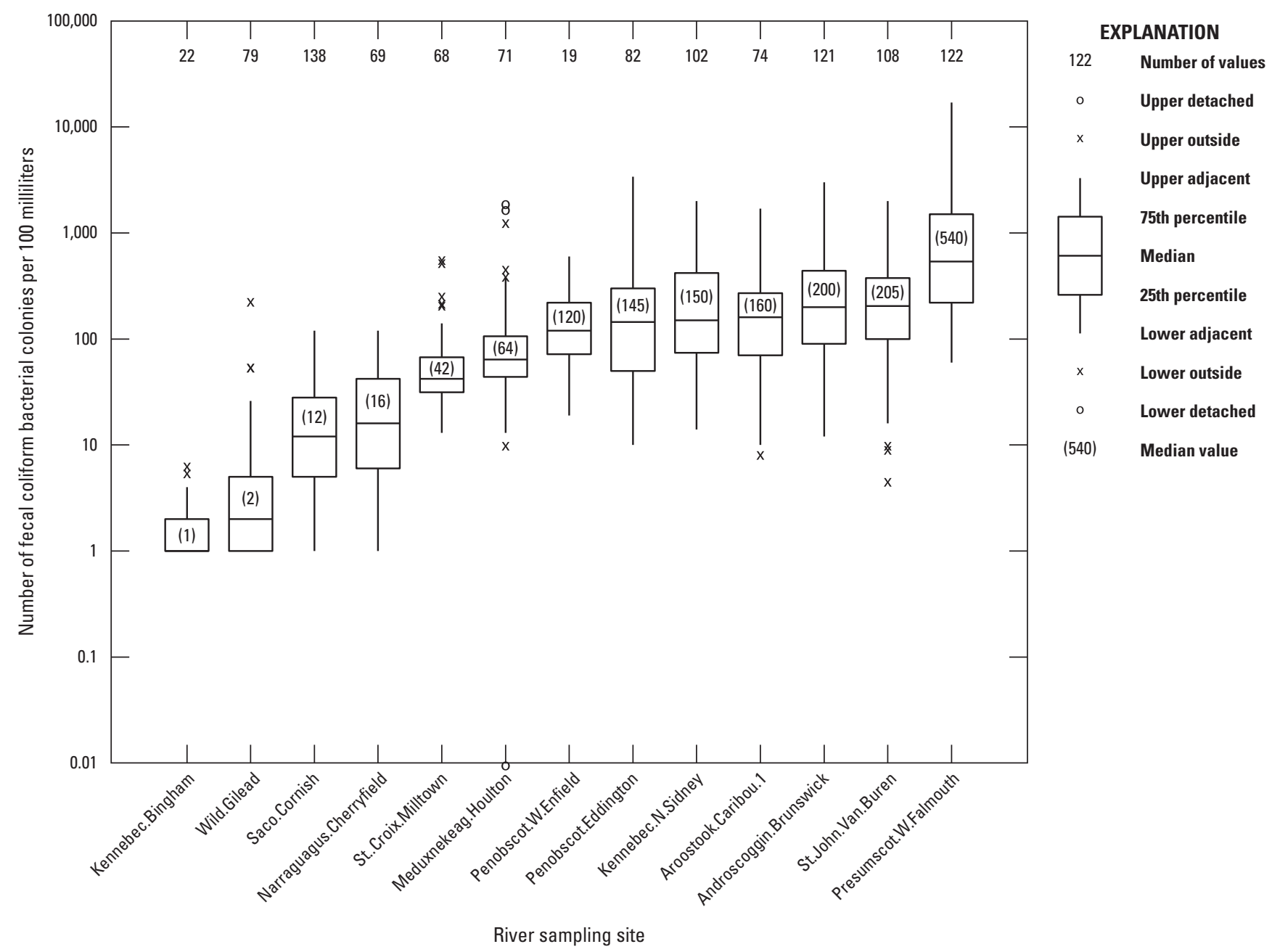

Figure 11. Bacterial counts (fecal-coliform colonies per 100 milliliters $[\mathrm{mL}]$ ) in surface-water samples collected from rivers in Maine during the NASQAN program from 1976 through 1994 and from the Meduxnekeag River downstream of urban areas near Houlton, Maine, from 1998 through 2005. 
densities to obtain more than 100 colonies (table 5). In eight samples, the number of colonies obtained and tested was between 19 and 80. For one sample (lab ID 397-03), esp marker was not tested because Enterococci were not cultivated from that sample. The human-associated esp gene was not detected in any test sample. The esp marker was detected in the reference feces sample of human origin from the Houlton wastewater-treatment plant (WWTP) (sample 506-04; table 5).

The detection limits of the Bacteroidales-based tests were determined by diluting a positive-control sample with different amounts of molecular-grade water to obtain a series of diminishing concentrations. These dilutions were then tested for the target by the use of PCR. For the general and humanassociated markers, a human septic positive-control sample was tested. For the ruminant-associated markers, the cattle positive-control DNA sample was used.

In each case, the sewage positive-control DNA samples were positive for the presence of the esp gene and for the Bacteroidales-based markers for general fecal contamination (Bac32) and human-origin fecal contamination (HF134 and HF183). In each case, the cattle positive-control DNA samples were positive for the Bacteroidales-based markers for general fecal contamination (Bac32) and ruminant fecal contamination (CF128 and CF193). The DNA concentration in a positive-control septic sample was 3.1 nanograms per microliter $(\mathrm{ng} / \mu \mathrm{L})$; the general marker was detectable down to the 1:3,000 dilution (approximately 1 picograms per microliter $[\mathrm{pg} / \mu \mathrm{L}])$, and the human-associated markers were detectable down to the 1:100 dilution (approximately $30 \mathrm{pg} / \mu \mathrm{L}$ ). The concentration of the positive-control ruminant DNA was $4.7 \mathrm{ng} / \mu \mathrm{L}$; the cattle-associated markers were detectable down to the $1: 1,000$ dilution (approximately $5 \mathrm{pg} / \mu \mathrm{L}$ ).

The positive-control reference human-feces sample (lab ID 506-04) was positive for esp marker, positive for Bacteroidales-based human markers (HF 134 and 183), positive for the Bacteroidales-based general fecal marker (Bac 32), and faint and negative for Bacteroidales-based ruminant markers (CF 128 and 193, respectively) (table 5). In this study, low incidence of Enterococci colony formation on $\mathrm{mEI}$ agar plates limited the detection of potential human markers in many samples; however, an ample number of Enterococci colonies were obtained from some samples, and a human-associated Bacteroidales marker was detected, but not the esp gene marker. Because the esp gene marker was detected in a Houlton WWTP sample (506-04) but not in the environmental samples, human fecal contamination detected by Bacteroidales markers likely did not come from the WWTP. Human fecal contamination, if present, could come from a small number of people where Bacteroidales markers are not detected. The faint detection of one ruminant marker (CF128) in the human reference sample (lab ID 506-04) indicates that either there was a component of ruminant feces in the waste stream from the WWTP, or that there was some cross-reactivity between the ruminant marker and the humanorigin waste sample.
The positive-control reference cattle-feces sample (lab ID 506-02) was negative for the esp marker, negative for the Bacteroidales-based human markers, positive for the Bacteroidales-based general fecal marker, and positive for the Bacteroidales-based ruminant markers. The detections of the ruminant-associated markers CF128 and CF193 indicate that ruminant (cattle) sources contributed fecal contamination. The absence of the ruminant-associated markers, in other samples, has three possible explanations: (1) The absence of ruminant-associated markers could indicate the absence of ruminant-origin fecal contamination; (2) the absence of ruminant-associated markers could also indicate that the concentration of fecal contamination from ruminant sources was lower than the detection limit of the method, or (3) the ruminants in the study area carry the CF128 and CF193 markers at an unusually low rate. The detection of the markers in the positive-control reference sample 506-02 indicates that the gene would be detected if ruminants (cattle) contributed fecal contamination to the sampled waters; therefore, one of the first two scenarios is correct and the third can be ruled out. The ruminant markers were not detected in a negative-control reference sample of horse fecal material (Fecal-Indicator Bacterial Fecal-Indicator Bacterial lab ID 506-03).

PCR blanks in each PCR run did not produce any PCR products, indicating a lack of contamination. The negativecontrol reference feces sample (reference horse-feces sample, lab ID 506-03) was negative for the presence of the esp gene and for the Bacteroidales-based markers for human-specific fecal contamination (HF134 and HF183) and ruminantspecific fecal contamination (CF128 and CF193). As would be expected, the negative-control DNA sample (506-01) was positive for Bac32, the Bacteroidales-based marker for general fecal contamination. The absence of marker detections in blank samples indicated that positive responses were not the result of PCR-mix contamination. The detection of markers in PCR positive-control DNA indicated that the markers, if present in environmental samples, would have been detected by the PCR reaction mixes created that day. The absence of detectable DNA $(0.06 \mathrm{ng} / \mu \mathrm{L}$, within detection noise $)$ and marker detections in the field blank (sample 506-01) indicated that the sample was not contaminated during transport and collection.

The detection of the Bac32 marker or HF134 in the matrix spikes indicated that if the Bacteroidales-based targets were present in the DNA extract, then they would have been detected (no matrix inhibition). The esp marker was not tested by matrix spikes in the environmental samples because the no-matrix inhibition had been detected in many previous runs. Matrix inhibition is considered less of an issue for enrichmentculture-based methods because the target is enriched away from inhibitors potentially present in the raw sample.

Among the Bacteroidales-based tests for the general fecal contamination (Bac32 marker), 20 were positive (table 5); most of these samples had excessive Enterococci fecal contamination as indicated by Enterococci densities greater than the USEPA criterion for Enterococci in 


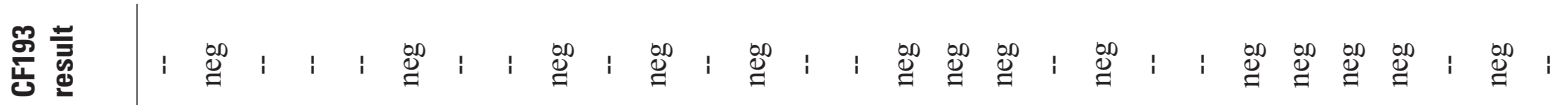

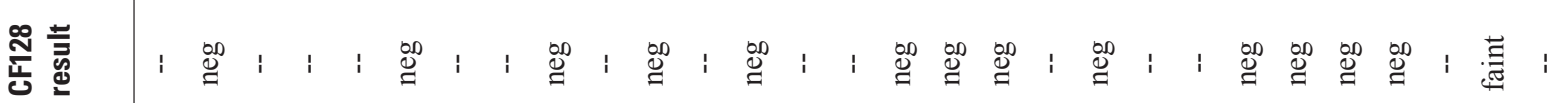

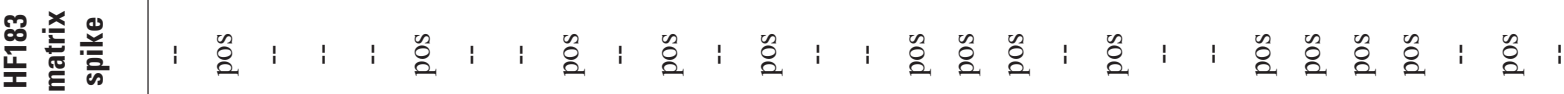

产言

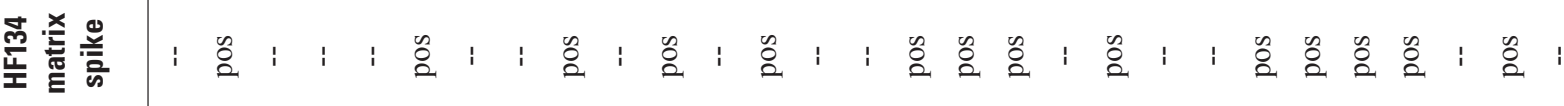

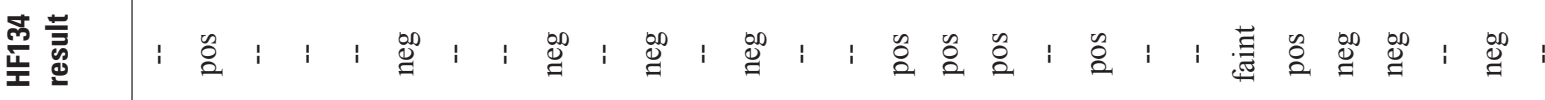

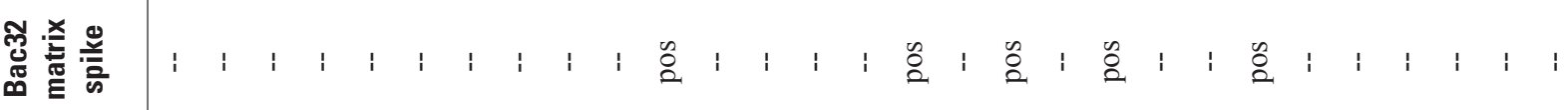

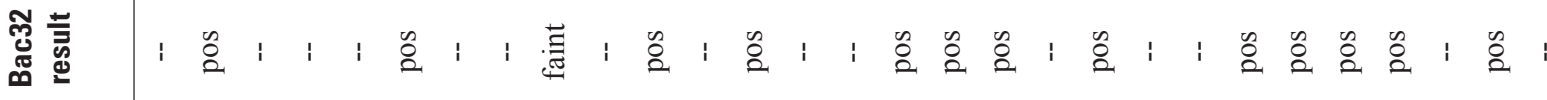

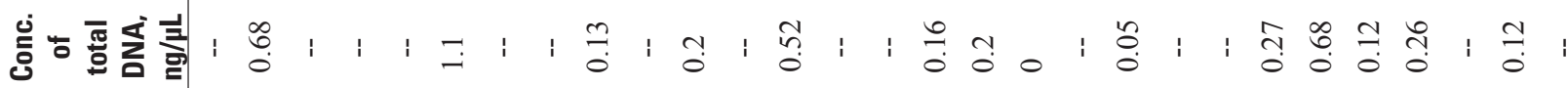

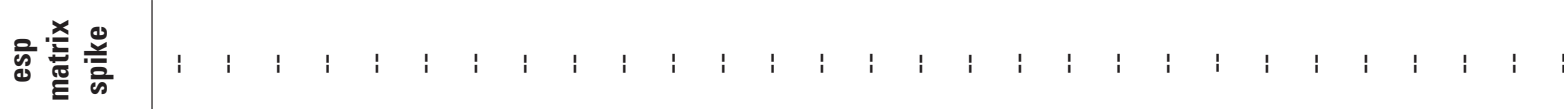

产离言

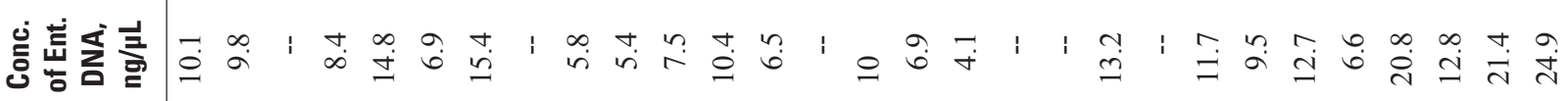

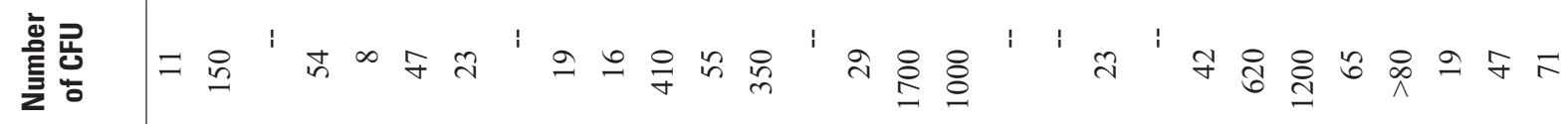
递立言

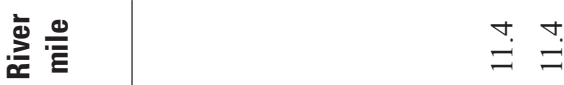

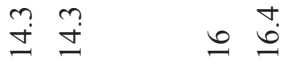

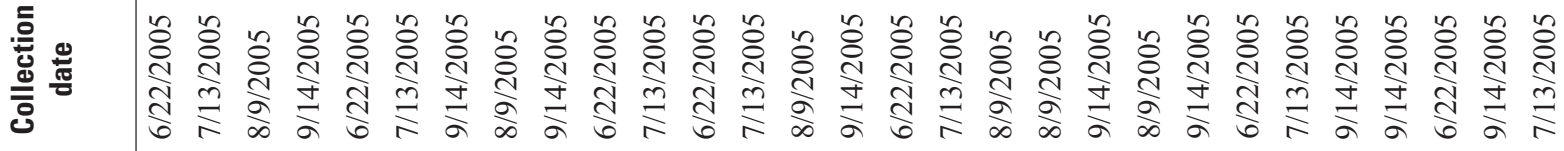
这

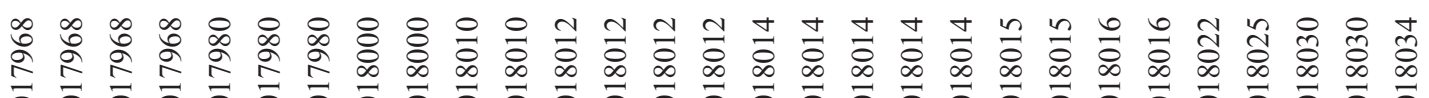

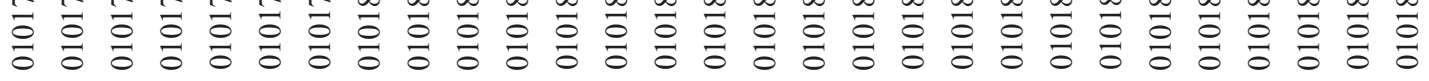

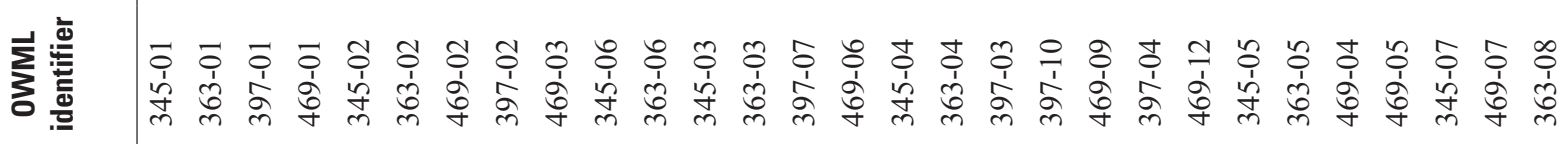




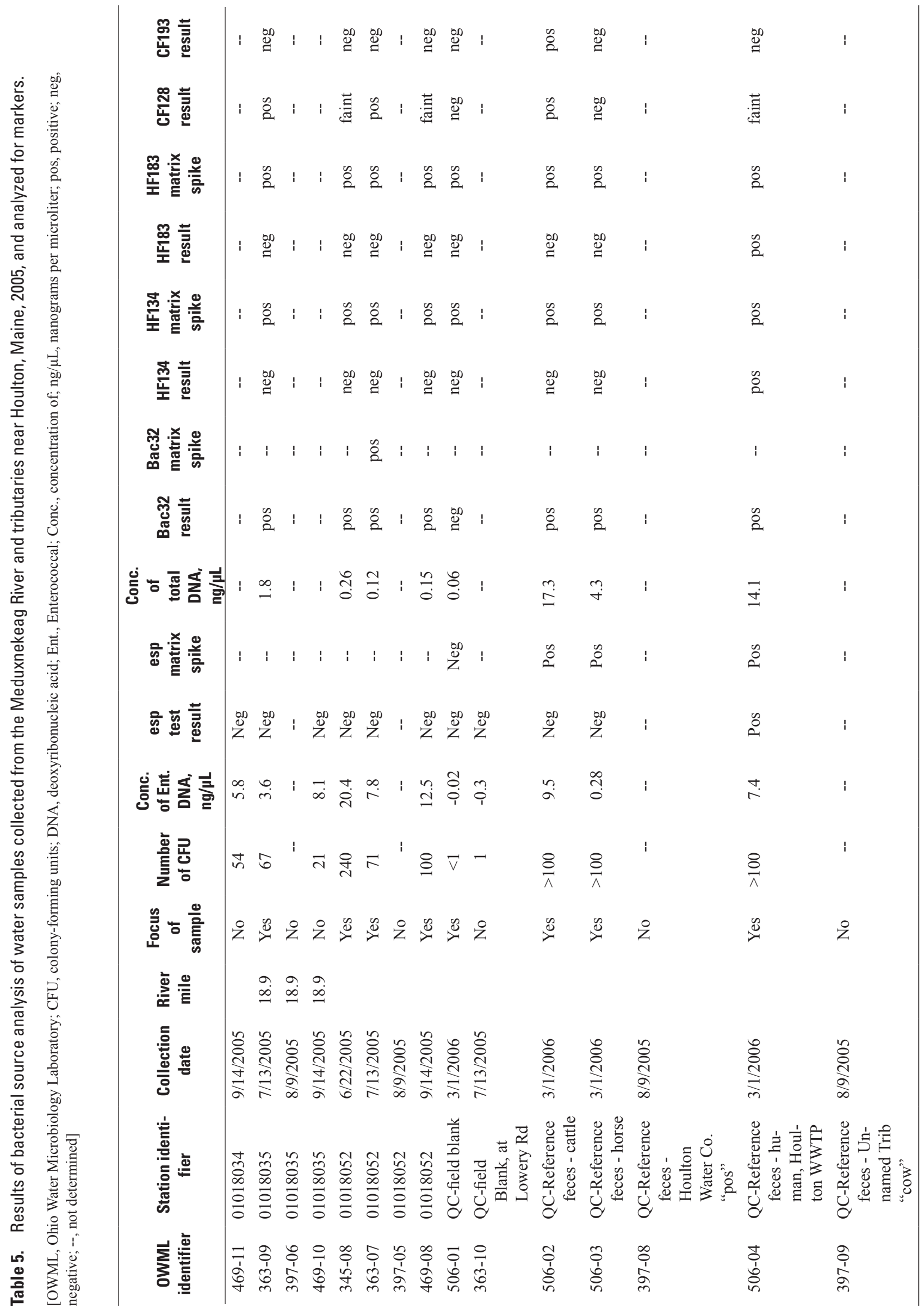


freshwater-recreational waters of 33 colonies per $100 \mathrm{~mL}$ (U.S. Environmental Protection Agency, 2002a). The test sample that was negative (not including the field blank) had the lowest amount of Enterococci contamination. Among the Bacteroidales-based tests for human-associated fecal contamination, eight were positive for HF134, and six were positive for HF183, including the human reference samples (table 5). Among the Bacteroidales-based tests for ruminantassociated fecal contamination, seven were positive for CF128, including the cattle reference sample; only the cattle reference sample was positive for CF193 (table 5).

Ruminant fecal markers were consistently detected at the Big Brook site. Ruminant markers were also detected in the only samples collected at each of two sites (Meduxnekeag River at Lowery Road (lab ID 363-09) and the unnamed tributary at Lowery Road (lab ID 469-07)), but not in samples collected at the other sites. The Big Brook watershed contains a high proportion of cultivated land and some hay and pasture land (figs. 1, 3). More of the land immediately adjacent to Big Brook is classified as cultivated crop land or pasture/hay than the land adjacent to other tributaries to the Meduxnekeag River (fig. 3).

\section{Enterococcus as an Indicator of Fecal Contamination}

The detection of the esp marker in Enterococci enrichment cultures may indicate the presence of humanorigin fecal contamination (Scott and others, 2005; Whitman and others, 2007). This marker was detected in samples from 80 percent of septic systems if the enrichment cultures contained at least 100 Enterococcus colonies per mL (Scott and others, 2005). In a prior OWML study (Dumouchelle, 2006), however, the esp marker was not detected in a composite sample from five septic tanks; if Enterococcus contamination is derived from small numbers of individuals, as is often true of samples collected from septic tanks, it may not be detected by this marker. The absence of the esp marker, however, does not necessarily mean that human sources did not contribute fecal contamination. The absence of the esp marker could indicate the absence of human-origin fecal contamination, but it could also indicate that culturable Enterococci from human sources carried the esp marker at a concentration below the detection limit (fewer than 1 in 100 colonies).

The detection of marker Bac32, HF134, and HF183 in a sample indicates fecal contamination but is not necessarily related to the amount of fecal contamination as indicated by fecal-indicator bacteria concentrations; a unit amount of fecal material does not always consist of the same proportions of fecal-indicator bacteria and Bacteroidales carrying the Bac32, HF134, and HF183 marker (Bower and others, 2005). In this study, nearly every sample had Enterococcal DNA above the estimated detection limit of approximately 0.001 nanograms per liter (ng/L) for general fecal coliform contamination. The
Bac32 marker was detected in every sample except the field blank. Some of the DNA extracted may have been of nonfecal origin. The detection of the HF134 and HF183 markers in the positive-control sample from the Houlton WWTP reference sample (506-04) indicates that the gene would be detected if humans contributed fecal contamination to the sampled waters; therefore, one of the first two scenarios above is correct and the third can be ruled out.

In this study, human fecal coliform contamination was detected fairly consistently at sites 1WAT and 1RIV, and in one sample from the Moose Brook site. Human fecal coliform markers were not detected at any other sites. This result shows that detection of human-associated markers was not necessarily related to high Enterococcus concentrations. Samples 363-03 and 363-06 had high Enterococcus concentrations but no detection of human-associated markers. Human-associated markers were detected in samples with ample fecal coliform contamination, indicated by high Enterococcus densities, with the exception of two samples collected at 1WAT (397-03 and 469-09). The concentration of total DNA in these two samples was low and associated with low FIB densities, yet human-associated markers were detected (table 5). On the basis of the estimated detection limit of the method, most of the DNA extracted from these samples likely was of human origin; thus, human waste appears to have been a major contributor of fecal contamination in this reach of the stream.

\section{Factors Associated with Distribution of Fecal Contamination}

Detections of fecal coliform bacteria tended to cluster first by site and then by date. The number of fecal coliform colony-forming units (CFUs) was consistently highest in samples collected from 1WAT and 1RIV (surface drains in the Houlton urban area). Samples from B Stream, Pearce Brook, and Big Brook contained fewer fecal coliform CFUs than samples collected from 1WAT and 1RIV, but more than samples collected from other tributaries or the main stem (table 5). For all sites (on tributaries, the main stem, and drains) with the exception of Big Brook and 1WAT, the density of fecal coliform CFUs detected during sampling for microbial sources was highest on July 13, 2005 and, except for 1WAT and 1RIV, substantially higher than the densities recorded for the other three sampling dates of June 22, 2005, August 9, 2005, and September 14, 2005. The July, 13, 2005, sampling date was the only one after more than $0.10 \mathrm{in}$. of rain during the preceding four days. A total of 0.87 in. of rain was recorded in Houlton during the four days before sampling, 0.58 in. of which fell during the two days before sampling (table 6). Contamination is apparently localized under normal flow conditions, with the highest levels restricted to drains in urban areas and to a lesser extent the tributaries B Stream, Pearce Brook, and Big Brook. Contamination was more widespread on July 13, 2005, following the storms 
Table 6. Rainfall (inches) on sampling dates for bacterial-source tracking and cumulative rainfall on 1-, 2-, 3-, and 4-day periods before sampling dates.

\begin{tabular}{lccccc}
\hline Date & $\begin{array}{c}\text { Rain on } \\
\text { sampling } \\
\text { date }\end{array}$ & $\begin{array}{c}\text { Rain on day be- } \\
\text { fore sampling } \\
\text { date }\end{array}$ & $\begin{array}{c}\text { Cumulative } \\
\text { rainfall on two } \\
\text { days before } \\
\text { sampling date }\end{array}$ & $\begin{array}{c}\text { Cumulative } \\
\text { rainfall on } \\
\text { three days be- } \\
\text { fore sampling } \\
\text { date }\end{array}$ & $\begin{array}{c}\text { Cumulative } \\
\text { rainfall on four } \\
\text { days before } \\
\text { sampling date }\end{array}$ \\
\hline $6 / 22 / 2005$ & 0.06 & 0.00 & 0.00 & 0.00 & 0.09 \\
$7 / 13 / 2005$ & 0.00 & 0.23 & 0.58 & 0.65 & 0.87 \\
$8 / 9 / 2005$ & 0.00 & 0.00 & 0.00 & 0.00 & 0.05 \\
$9 / 14 / 2005$ & 0.00 & 0.00 & 0.00 & 0.00 & 0.00 \\
\hline
\end{tabular}

in mid-July; these results indicate that storm runoff likely contributed fecal coliform contamination over a wider area than under conditions of lower flow.

The detection of the general fecal contamination marker Bac32 confirmed the results observed for densities of fecal coliform bacteria CFUs, where detections tended to cluster first by site and then by date (table 5). Contamination, as indicated by detection of Bac32, is also apparently localized under normal flow conditions with the highest frequency of hits restricted to drains in urban areas and to a lesser extent the tributaries B Stream, Pearce Brook, and Big Brook. Contamination was more widespread on July 13, 2005 , following the storms in mid-July, again supporting the notion that storm runoff likely contributed fecal coliform contamination over a wider area than under conditions of lower flow.

\section{Summary}

The U.S. Geological Survey, in cooperation with the Houlton Band of Maliseet Indians (HBMI), assessed samples from the Meduxnekeag River in northeastern Maine in 2005 to investigate potential sources of contamination from fecal coliform bacteria. Concentration and distribution data collected by the HBMI on fecal coliform bacteria indicated that bacterial contamination enters the Meduxnekeag River from multiple paths, including tributaries and surface drains (ditches) in developed areas in Houlton, Maine. Bacterial contamination is most closely associated with increasing development and is lowest in the upper reaches of forested watersheds. Bacteroidales-based tests for the general fecal-contamination marker (Bac32) were largely positive and indicated excessive fecal coliform contamination by Enterococci. Of the 22 Bacteroidales-based tests for humanassociated fecal contamination, 8 were positive. Of the
22 Bacteroidales-based tests for ruminant-associated fecal contamination, 7 were positive. Contamination by fecal coliform bacteria is apparently localized under normal flow conditions with the highest levels restricted to drains in urban areas and, to a lesser extent, the tributaries B Stream, Pearce Brook, and Big Brook. More widespread contamination on July 13, 2005, following storms in mid-July of that year indicated that storm runoff likely mobilized fecal coliform bacteria in more locations than under conditions of lower flow. Deoxyribonucleic acid (DNA) extracted from one of the surface drains in the Houlton urban area indicated that DNA was of human fecal origin; this result provided evidence that human waste was a major contributor of fecal contamination in this stream.

Coliphage were enumerated as an alternate indicator of fecal contamination with the intent of typing the virus into host-associated classes (human or ruminant), as was done for Enterococci; however, insufficient coliphage were isolated to provide more than preliminary indications. Analysis of DNA from limited sample material indicated the likely presence of the human-associated marker HF134 only in the reference sample of human feces from the Houlton wastewater-treatment plant (WWTP) and in samples from surface drains (1WAT, 1RIV) and Moose Brook. The human-associated marker HF183 was also detected in the reference sample of human feces from the Houlton WWTP and in samples from the 1WAT and 1 RIV sites. The ruminant-associated marker CF128 was detected in samples collected from the unnamed tributary to the Meduxnekeag River at Lowery Road, the Meduxnekeag River at Lowery Road, Big Brook, and in the cattle feces reference sample (506-02). The CF193 ruminant marker was detected only in the cattle reference sample (506-02). In spite of low coliphage enumeration, these preliminary results strengthen the conclusion that the Enterococci data correctly indicated the samples that contained human and ruminant fecal contamination. 


\section{References Cited}

Alexander, R.B., Ludtke, A.S., Fitzgerald, K.K., and Schertz, T.L., 1996, Data from selected U.S. Geological Survey National Stream Water-Quality Monitoring Networks (WQN) on CD-ROM: U.S. Geological Survey Open-File Report 96-337, 79 p.

Arno, J.R. 1964, Soil survey of Aroostook County, southern part: Washington, D.C., Soil Conservation Service (now Natural Resources Conservation Service), U.S. Department of Agriculture, Series 1961, no. 6, 62 p. with 123 map plates, accessed August 7, 2012, at ftp://ftp-fc.sc.egov.usda. gov/ME/soilsurveys/saroostook.pdf.

Aroostook Water and Soil Management Board, 1996, How to deal with low flow periods and irrigating farmer's and environmental concerns in Aroostook County: Presque Isle, Maine, Aroostook Water and Soil Management Program, 8 p.

Bales, J.D., and Nardi, M.R., 2007, Automated routines for calculating whole-stream metabolism-Theoretical background and user's guide: U.S. Geological Survey Techniques and Methods, book 4, chap. C2, 33 p.

Bernhard, A.E., and Field, K.G., 2000, A PCR assay to discriminate human and ruminant feces on the basis of host differences in Bacteroides-Prevotella genes encoding 16S rRNA: Applied and Environmental Microbiology, v. 66, no. 10, p. 4571-4574.

Bower, P.A., Scopel, C.O., Jensen, E.T., Depas, M.M., and McLellan, S.L., 2005, Detection of genetic markers of fecal indicator bacteria in Lake Michigan and determination of their relationship to Escherichia coli densities using standard microbiological methods: Applied and Environmental Microbiology, v. 71, no, 12, p. 8305-8313.

Bordner, Robert, Winter, J.A., Scarpino, P.V., eds., 1978, Microbiological methods for monitoring the environmentWater and wastes: Cincinnati, Ohio, Environmental Protection Agency, Environmental Monitoring and Support Laboratory, Office of Research and Development, EPA-600/8-78-017.

Clark, M.L., and Gamper, M.E., 2003, A synoptic study of fecal-indicator bacteria in the Wind River, Bighorn River, and Goose Creek basins, Wyoming, June-July 2000: U. S. Geological Survey Water-Resources Investigations Report 03-4055, $43 \mathrm{p}$.

Culbertson, C.W., Huntington, T.G., Caldwell, J.M., and O'Donnell, Cara, 2012, Evaluation of aerial infrared remote sensing to identify groundwater-discharge zones in the Meduxnekeag River, Houlton, Maine: U.S. Geological Survey Open-File Report 2013-1168, 21 p.
Dombek, P.E., Johnson, L.A.K., Zimmerley, S.T., and Sadowsky, M.J., 2000, Use of repetitive DNA sequences and the PCR to differentiate Escherichia coli isolates from human and animal sources: Applied and Environmental Microbiology, v. 66, no. 6, p. 2572-2577.

Dumouchelle, D.H, 2006, Use of DNA markers for investigating sources of bacteria in contaminated ground water-Wooster Township, Wayne County, Ohio: U.S. Geological Survey Open-File Report 2006-1382, 13 p.

Field, K.G., and Samadpour, M., 2007, Fecal source tracking, the indicator paradigm, and managing water quality: Water Research, v. 41, no. 16, p. 3517-3538.

Fishman, M.J., 1993, Methods of analysis by the U. S. Geological Survey National Water Quality LaboratoryDetermination of inorganic and organic constituents in water and fluvial sediments: U.S. Geological Survey Open-File Report 93-125, 217 p.

Fontaine, R.A., Herrick, E., and Norman, N., 1982, Drainage areas of surface water bodies of the St. John River basin in northern Maine: U.S. Geological Survey Open-File Report 78-556G, 70 p.

Fretwell, E.A., 2006, The temporal and spatial relationship between phosphorus and nitrogen concentrations, algal growth, and nutrient sources in the Meduxnekeag River watershed: Orono, Maine, University of Maine, Master of Science thesis, 128 p.

Goldstein, R.M., Schalk, C.W., and Kempf, J.P., 2009, Primary productivity in Meduxnekeag River, Maine, 2005: U.S. Geological Survey Scientific Investigations Report 2009-5029, 15 p., accessed August 7, 2012 at http://pubs. usgs.gov/sir/2009/5029/.

Hsu, F.C., Shieh, Y.S., van Duin, J., Beekwilder, M.J., and Sobsey, M.D., 1995, Genotyping male-specific RNA coliphages by hybridization with oligonucleotide probes: Applied and Environmental Microbiology, v. 61, no. 11, p. 3960-3966.

Maine Department of Environmental Protection, 1998a, Maine Section 303(d) waters - 1998: Maine Department of Environmental Protection, accessed February 5, 2004 at http://www.state.me.gov/dep/blwq/ docmonitoring/303d981.pdf.

Maine Department of Environmental Protection, 1998b, State of Maine unified watershed assessment: Maine Department of Environmental Protection, accessed March 8, 2004 at http://www.maine.gov/dep/blwq/docwater-shed/ uwacate2.pdf.

Maine Department of Environmental Protection, 2000, Meduxnekeag River TMDL (Final): Maine Department of Environmental Protection, Division of Environmental Assessment, DEPLW2000-22, 13 p. 
Maine Department of Environmental Protection, 2002, Integrated water quality and monitoring assessment report: Maine Department of Environmental Protection, accessed March 8, 2004 at http://www.maine.gov/dep/ blwq/2002Appendix.pdf.

Maine Department of Environmental Protection, 2003, Status of licensed discharges: Maine Department of Environmental Protection, accessed February 5, 2004 at http://www.maine. gov/dep/blwq//report/statuslicenseddischarge03.pdf.

Meays, C.L., Broersma, K., Nordin, R., and Mazumder, A., 2004, Source tracking fecal bacteria in water-A critical review of current methods: Journal of Environmental Management, v. 73, no. 1, p. 71-79.

National Oceanic and Atmospheric Administration, 2002, Monthly station normals of temperature, precipitation, and heating and cooling degree days, 1971-2000, Maine: Asheville, N.C., National Climate Data Center, Climatography of the United States, no. 81, 16 p.

National Oceanic and Atmospheric Administration, 2005, Climatological Data, New England, v. 117, no. 1-12: National Climate Data Center, variously paginated.

Schalk, C.W., and Tornes, Lan, 2005, Nutrients, organic compounds, and mercury in the Meduxnekeag River watershed, Maine, 2003: U.S. Geological Survey Scientific Investigations Report 2005-5111, $31 \mathrm{p}$.

Scott, T.M., Jenkins, T.M., Lukasik, Jerzy, and Rose, J.B., 2005, Potential use of a host associated molecular marker in Enterococcus faecium as an index of human fecal pollution: Environmental Science and Technology, v. 39, no. 1, p. 283-287.

Scott, T.M., Rose, J.B., Jenkins, T.M., Farrah, S.R., and Lukasik, Jerzy, 2002, Microbial source trackingCurrent methodology and future directions: Applied and Environmental Microbiology, v. 68, no. 12, p. 5796-5803.

Simpson, J.M., Santo Domingo, J.W., and Reasoner, D.J., 2002, Microbial source tracking - State of the science: Environmental Science and Technology, v. 36, no. 24, p. 5279-5288.

Smith, R.A., and Alexander, R.B., 1982, A study of trends in dissolved oxygen and fecal coliform bacteria at NASQAN stations: U.S. Geological Survey Open-File Report 82-1019, 6 p.

Smith, R.A., Alexander, R.B., and Wolman, M.G., 1987, Water quality trends in the Nation's rivers: Science, v. 235, no. 4796 , p. $1607-1615$.
Southern Aroostook County Soil and Water Conservation District, 1993, Watershed protection plan, environmental assessment, main branch Meduxnekeag River watershed, Aroostook County, Maine: Southern Aroostook County Soil and Water Conservation District, Houlton Band of Maliseet Indians, Houlton, Maine, 86 p.

Stoeckel, D.M., 2005, Selection and application of microbial source tracking tools for water-quality investigations: U.S. Geological Survey Techniques and Methods, book 2, chap. A3, 43 p.

Stoeckel, D.M., and Harwood, V.J., 2007, Performance, design, and analysis in microbial source tracking studies: Applied and Environmental Microbiology, v. 73, no. 8, p. 2405-2415.

Thompson, W.B., and Borns, H.W., Jr., eds., 1985, Surficial geologic map of Maine: Maine Geological Survey, Department of Conservation, 1 pl., scale 1:500,000.

Town of Houlton, 2004, Regional economic development and strategic marketing plan: Houlton, Maine, Jim Damicis Associates, $93 \mathrm{p}$.

U.S. Census Bureau, 2010, Population Map: accessed on August 7, 2012, at http://2010.census.gov/2010census/ popmap/.

U.S. Department of Agriculture, Natural Resources Conservation Services, 1994, State soil geographic (STATSGO) database, data use information: Lincoln, Nebraska, National Soil Survey Center Miscellaneous Publication 1492, 39 p., appendixes.

U.S. Environmental Protection Agency, 1990, National water quality inventory - 1988 report to Congress: Office of Water, Washington, D.C., 266 p.

U.S. Environmental Protection Agency, 1996, Environmental indicators of water quality in the United States: Washington, D.C., U.S. Environmental Protection Agency, Office of Water (4503F), EPA 841-R-96-002, 30 p.

U.S. Environmental Protection Agency, 2000, Progress in water quality-An evaluation of the national investment in municipal wastewater treatment: Washington, D.C., U.S. Environmental Protection Agency, Office of Wastewater Management, EPA-832-R-00-008.

U.S. Environmental Protection Agency, 2001, Method 1602Male-specific $\left(\mathrm{F}^{+}\right)$and somatic coliphage in water by single agar layer (SAL) procedure: Washington, D.C., U.S. Environmental Protection Agency, EPA-821-R-01-029, $30 \mathrm{p}$. 
U.S. Environmental Protection Agency, 2002a, Implementation guidance for ambient water quality criteria for bacteria: Washington, D.C.,U.S. Environmental Protection Agency, Draft EPA-823-B-02-003, 91 p.

U.S. Environmental Protection Agency, 2002b, National water quality inventory: Washington, D.C., U.S. Environmental Protection Agency, EPA-841-R-02-001, 207 p.

U.S. Environmental Protection Agency, 2002c, Method 1600 - Enterococci in water by membrane filtration using membrane-Enterococcus Indoxyl- $\beta$-D-Glucoside agar (mEI): Washington, D.C., EPA-821-R-02-022, 14 p.

U.S. Environmental Protection Agency, 2002d, Method 1603 - Escherichia coli in water by membrane filtration using modified membrane-thermotolerant Escherichia coli agar: Washington, D.C., EPA-821-R-02-023, 15 p.

U.S. Environmental Protection Agency, 2003, Protecting water quality from urban runoff: Washington, D.C., U.S. Environmental Protection Agency, EPA-841-F-03-003, $2 \mathrm{p}$.

U.S. Environmental Protection Agency, 2005, Protecting water quality from agricultural runoff-Clean water is everybody's business: Washington, D.C., U.S. Environmental Protection Agency, EPA-841-F-05-001, 2 p.

Whitman, R.L., Kelly, K. P., Shively, D.A., and Byappanahalli, M.N., 2007, Incidence of the Enterococcal surface protein (esp) gene in human and animal fecal sources: Environmental Science and Technology, v. 41, no. 17, p. 6090-6095. 

Prepared by the Pembroke Publishing Service Center.

For more information concerning this report, contact:

Office Chief

U.S. Geological Survey

New England Water Science Center

Maine Office

196 Whitten Road

Augusta, ME 04330

dc_me@usgs.gov

or visit our Web site at:

http://me.water.usgs.gov 


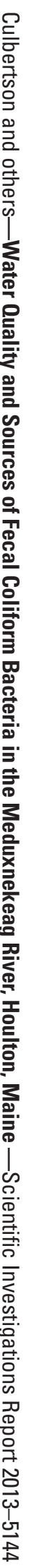

